\title{
Human Nephrosclerosis Triggers a Hypoxia-Related Glomerulopathy
}

\author{
Matthias A. Neusser, ${ }^{*}$ Maja T. Lindenmeyer, ${ }^{\dagger \neq}$ \\ Anton G. Moll, ${ }^{\ddagger}$ Stephan Segerer, ${ }^{\dagger \S}$ \\ Ilka Edenhofer, ${ }^{\dagger \neq}$ Kontheari Sen, ${ }^{\ddagger}$ \\ Daniel P. Stiehl, ${ }^{\ddagger}$ Matthias Kretzler, ${ }^{4}$ \\ Hermann-Josef Gröne," Detlef Schlöndorff, ** \\ and Clemens D. Cohen ${ }^{\dagger \ddagger}$ \\ From the Clinic and Policlinic for Internal Medicine* and the \\ Division of Nephrology, ${ }^{\dagger}$ University Hospital Zurich, Zurich, \\ Switzerland; the Institute of Physiology with Zurich Center of \\ Integrative Human Physiology, ${ }^{\ddagger}$ and the Institute of Anatomy, ${ }^{\S}$ \\ University of Zurich, Zurich, Switzerland; the Department of \\ Medicine, "Iniversity of Michigan, Ann Arbor, Michigan; the \\ Department of Cellular and Molecular Pathology," German \\ Cancer Research Center Heidelberg, Germany; and the \\ Department of Medicine,** Mount Sinai School of Medicine, \\ New York, New York
}

In the kidney, hypoxia contributes to tubulointerstitial fibrosis, but little is known about its implications for glomerular damage and glomerulosclerosis. Chronic hypoxia was hypothesized to be involved in nephrosclerosis (NSC) or "hypertensive nephropathy." In the present study genome-wide expression data from microdissected glomeruli were studied to examine the role of hypoxia in glomerulosclerosis of human NSC. Functional annotation analysis revealed prominent regulation of hypoxia-associated biological processes in NSC, including angiogenesis, fibrosis, and inflammation. Glomerular expression levels of a majority of genes regulated by the hypoxia-inducible factors (HIFs) were significantly altered in NSC. Among these HIF targets, chemokine C-X-C motif receptor 4 (CXCR4) was prominently induced. Glomerular CXCR4 mRNA induction was confirmed by quantitative RT-PCR in an independent cohort with NSC but not in those with other glomerulopathies. By immunohistological analysis, CXCR4 showed enhanced positivity in podocytes in NSC biopsy specimens. This CXCR4 positivity was associated with nuclear localization of HIF1 $\alpha$ only in podocytes of NSC, indicating transcriptional activity of HIF. As the CXCR4 ligand CXCL12/SDF-1 is constitutively expressed in podocytes, autocrine signaling may contribute to NSC. In addition, a blocking CXCR4 antibody caused signifi- cant inhibition of wound closure by podocytes in an in vitro scratch assay. These data support a role for CXCR4/CXCL12 in human NSC and indicate that hypoxia not only is involved in tubulointerstitial fibrosis but also contributes to glomerular damage in NSC. (Am J Pathol 2010, 176:594-607; DOI: 10.2353/ajpath.2010.090268)

Hypoxia is considered a pivotal factor contributing to tubular atrophy and interstitial fibrosis, which are factors for the progression of renal disease. ${ }^{1}$ The evidence in support of this hypothesis derives mostly from experimental animal studies. ${ }^{2-5}$ Most of these have focused on the tubulointerstitial space with little attention being paid to the glomerulus. The cellular response to hypoxia is largely mediated by heterodimeric transcription factors, the hypoxia-inducible factors (HIFs). ${ }^{2}$ The cellular levels of the HIF $1 \alpha$ and HIF2 $\alpha$ subunits (HIF $\alpha$ ) of HIF (gene symbols HIF1A and HIF2A) are controlled mainly by posttranslational protein modification. Under normoxia HIF $\alpha$ is degraded by the von Hippel-Lindau tumor suppressor protein. This process is regulated by oxygen-dependent hydroxylation of HIF $\alpha$ through specific prolyl hydroxylases. Under hypoxic conditions degradation of $\mathrm{HIF} \alpha$ ceases and the stabilized protein can function as a transcription factor. ${ }^{2}$ In the renal glomerulus, a functional role of HIF $1 \alpha^{6-8}$ and HIF2 $\alpha^{9}$ has been documented in podocytes of rodents. Recently, glomerular podocyte-specific deletion of von Hippel-Lindau tumor suppressor protein was achieved in mice, resulting in podocyte-specific overactivity of HIF with induction of HIF target genes. ${ }^{6,8}$

Supported by the Else Kröner-Fresenius Foundation (A62/04 to C.D.C.) and the Swiss National Science Foundation (32-122439/1 to C.D.C.) and in part by the National Institutes of Health (National Institute of Diabetes and Digestive and Kidney Diseases R01-DK081420-01 to D.S.) and the Deutsche Forschungsgemeinschaft (SFB405-B10 to H.-J.G.).

M.A.N., M.T.L., and A.G.M., contributed equally to this work.

Accepted for publication September 29, 2009.

Supplemental material for this article can be found on http://ajp. amjpathol.org

Address reprint requests to Clemens D. Cohen, M.D., Institute of Physiology and Division of Nephrology, University and University Hospital of Zurich, Winterthurerstr. 190 (23-J-74), 8057 Zurich, Switzerland. E-mail: clemens.cohen@access.uzh.ch. 
Podocyte-specific HIF activation led to overexpression of chemokine (C-X-C motif) receptor 4 (CXCR4) in podocytes. ${ }^{8}$ This was associated with progressive glomerular damage and crescent formation, raising the question of whether hypoxia may also play a prominent role in glomerular pathology. ${ }^{8}$

The aim of the present study was to investigate the potential role of hypoxia in common glomerulopathies such as nephrosclerosis (NSC). NSC constitutes the second most common cause for end-stage renal disease in the Western world, next to diabetic nephropathy. ${ }^{10}$ NSC is also known under different synonyms such as hypertensive nephropathy or "benign" nephrosclerosis. The diagnosis of NSC is based on histological criteria including segmental hyalinosis mainly within the walls of afferent arterioles and subendothelial fibrosis of interlobular arteries, as well as focal and segmental glomerulosclerosis and glomerular collapse. ${ }^{1-13}$ The exclusion of other known causes of renal disease, such as long-standing diabetes mellitus, autoimmune disease, or exposure to nephrotoxins is part of the diagnostic work-up. ${ }^{14,15}$ Arterial hypertension is an important contributory factor but is not a conditio sine qua non. ${ }^{13,14,16}$ Genetic susceptibility factors may modulate development and progression of glomerular sclerosis. Recently, genetic variants such as single nucleotide polymorphisms in the gene $\mathrm{MYH}$, which encodes nonmuscle myosin heavy chain type II isoform A, were found to be associated with nondiabetic end-stage renal disease in African Americans, probably including a considerable number with NSC. ${ }^{17-19}$ Although the pathogenesis of NSC remains to be clearly defined, it has been hypothesized that a prominent pathomechanism in NSC may be glomerular ischemia due to luminal narrowing of the preglomerular arteriole. ${ }^{20,21}$

This situation prompted us to perform systematic analyses on gene expression data sets from microdissected human renal biopsy specimens from patients with NSC. We hypothesized that local hypoxia leading to transcriptional activity of HIF may play a key role in the development and progression of NSC. This activation of HIF target genes may influence, among others, three major processes involved in the progression of renal disease, ie, angiogenesis, fibrosis, and inflammation. ${ }^{1}$ This hypothesis is supported by the reported gene expression data, as a large number of known HIF target genes, including CXCR4, are induced in glomeruli from patients with NSC. HIF1 $\alpha$ was selected as a marker of hypoxia-associated transcriptional activation and was demonstrated in nuclei of NSC podocytes by immunohistological analysis. These data and supporting in vitro studies provide considerable evidence that local hypoxia contributes to the progression of glomerulosclerosis in NSC.

\section{Materials and Methods}

\section{Renal Biopsy Specimens for mRNA Analysis}

Human renal biopsy specimens were procured in an international multicenter study, the European Renal cDNA Bank-Kröner-Fresenius biopsy bank (see Acknowledgments for participating centers). ${ }^{22}$ Biopsy specimens were obtained from patients after informed consent and with approval of local ethics committees. Affymetrix HGU133A microarrays were hybridized with glomerular cDNA procured from 14 patients with NSC. Specific attention was paid to the clinical and histological criteria of NSC mentioned in the Introduction. ${ }^{11-15}$ For diagnosis of NSC, light microscopic and immunofluorescence examination was performed on all samples, and electron microscopic examination was performed on all but three biopsy specimens (NSC1, NSC2, and NSC18). Tumorfree kidney specimens from patients undergoing tumor nephrectomy (TN) served as control tissues. Confirmatory real-time RT-PCR analyses were performed on microdissected glomeruli from biopsy specimens from an independent cohort of patients with NSC $(n=13)$, primary focal segmental glomerulosclerosis (FSGS) $(n=$ 18), IgA nephropathy (IgAN) $n=15)$, and minimal change disease (MCD) $(n=12)$. Pretransplant kidney biopsy specimens from living renal allograft donors (LDs) $(n=6)$ served as controls. Clinical and histological characteristics of the patients and biopsy specimens are summarized in Table 1.

\section{RNA Isolation, Preparation, and Microarray Experiments}

After renal biopsy, the tissue was transferred to an RNase inhibitor and microdissected into glomerular and tubular specimens. Total RNA was isolated from microdissected glomeruli, reverse-transcribed, and linearly amplified according to a protocol reported previously. ${ }^{23}$ Fragmentation, hybridization, staining, and imaging were performed according to the Affymetrix Expression Analysis Technical Manual for HG-U133A. Before microarray analysis Robust Multichip Average was applied. To exclude highly variable nonexpressed or low-expressed probe sets we defined a filter cutoff using the highest signal value obtained from a nonhuman Affymetrix control probe set multiplied by a factor of 1.2 , corresponding in the current data set to a log2-based value of $6.81 .{ }^{24}$ The expression data are made available online at http://www.nephromine. org. Subsequently we analyzed the differential expression with significance analysis of microarrays ${ }^{25}$ The main results were also confirmed in a probe set-independent analysis (ChipInspector, Genomatix, Munich, Germany). ${ }^{26}$ In a further step, the probe sets of a group of selected genes above cutoff were hierarchically clustered using dChip software. ${ }^{27}$ The Euclidean distance metric was chosen, and clusters were merged using average linkage. Gene lists derived from the literature were mapped to the default Affymetrix annotation using Human Genome Organization gene symbols.

\section{Analysis of Biological Processes}

Database for Annotation, Visualization and Integrated Discovery (DAVID, version 2007) is a web- and literaturebased functional annotation tool, which allows systematic grouping of biologically related genes from user-classified gene lists, thereby highlighting the most relevant 
Table 1. Clinical and Histological Characteristics of Biopsy Specimens from Patients with NSC, FSGS, IgAN, and MCD and Controls

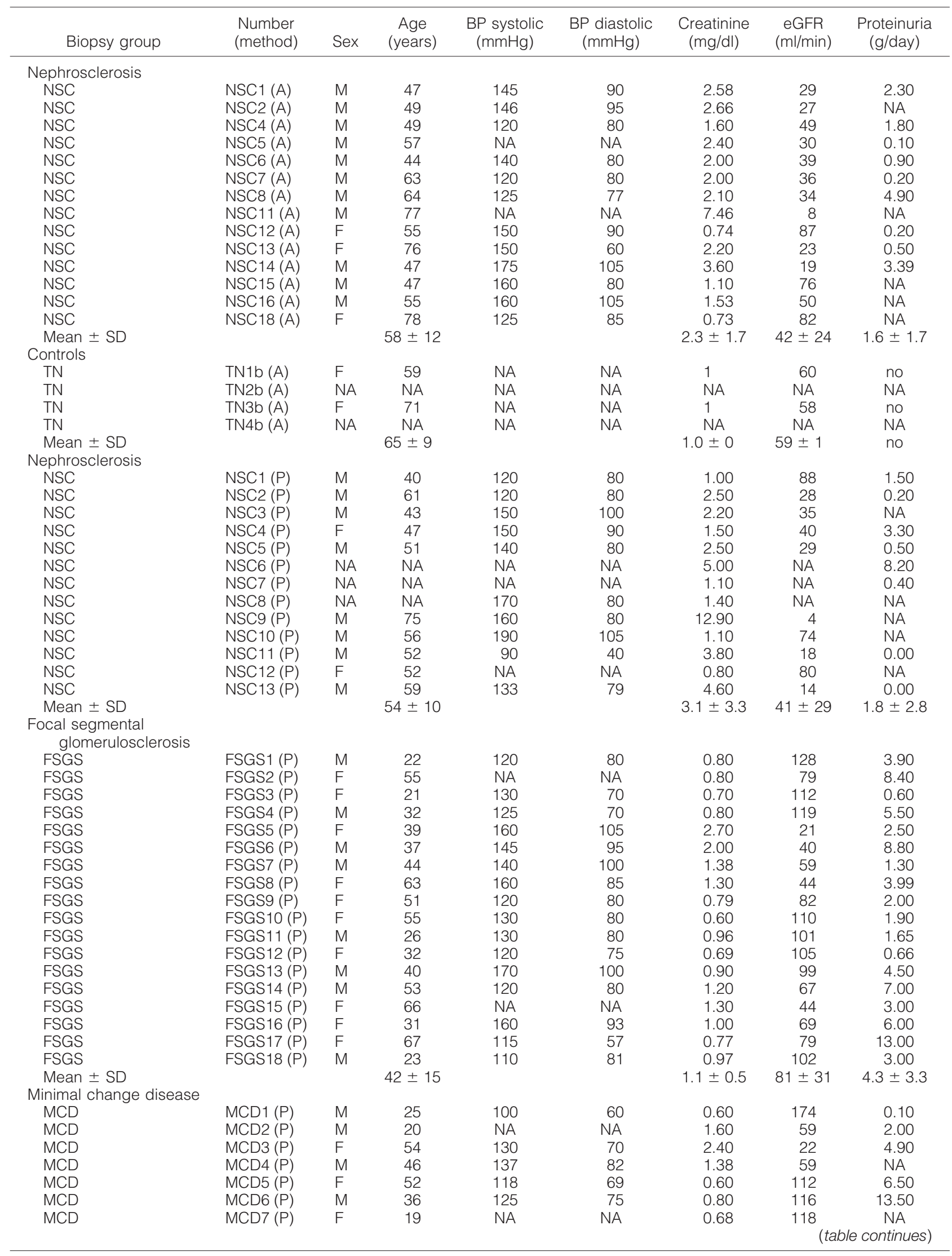


Table 1. Continued

\begin{tabular}{|c|c|c|c|c|c|c|c|c|}
\hline Biopsy group & $\begin{array}{l}\text { Number } \\
\text { (method) }\end{array}$ & Sex & $\begin{array}{c}\text { Age } \\
\text { (years) }\end{array}$ & $\begin{array}{l}\text { BP systolic } \\
(\mathrm{mmHg})\end{array}$ & $\begin{array}{l}\text { BP diastolic } \\
(\mathrm{mmHg})\end{array}$ & $\begin{array}{c}\text { Creatinine } \\
(\mathrm{mg} / \mathrm{dl})\end{array}$ & $\begin{array}{l}\text { eGFR } \\
\text { (ml/min) }\end{array}$ & $\begin{array}{c}\text { Proteinuria } \\
\text { (g/day) }\end{array}$ \\
\hline MCD & MCD8 (P) & $\mathrm{F}$ & 45 & NA & NA & 0.54 & 130 & 14.80 \\
\hline MCD & MCD9 (P) & $\mathrm{F}$ & 32 & 125 & 85 & 0.70 & 103 & 3.00 \\
\hline MCD & MCD10 (P) & M & 16 & 135 & 100 & 1.20 & 84 & 5.40 \\
\hline MCD & MCD11 (P) & $\mathrm{F}$ & 20 & 110 & 70 & 0.50 & 167 & 6.00 \\
\hline MCD & MCD12 (P) & M & 32 & 150 & 90 & 1.30 & 68 & 11.00 \\
\hline \multicolumn{8}{|l|}{ IgA nephropathy } & $6.7 \pm 4.9$ \\
\hline IgAN & IgAN1 (P) & M & 35 & 130 & 80 & 1.40 & 61 & 0.30 \\
\hline $\operatorname{IgAN}$ & IgAN2 (P) & $\mathrm{F}$ & 35 & 120 & 70 & 0.72 & 98 & 0.28 \\
\hline $\operatorname{IgAN}$ & $\operatorname{IgAN} 3(P)$ & $\mathrm{F}$ & 22 & 120 & 70 & 0.90 & 83 & 0.70 \\
\hline IgAN & IgAN4 (P) & $\mathrm{F}$ & 24 & 130 & 70 & 0.60 & 131 & 0.70 \\
\hline $\operatorname{IgAN}$ & IgAN5 (P) & M & 51 & 120 & 75 & 0.80 & 108 & NA \\
\hline IgAN & IgAN6 (P) & M & 35 & NA & NA & 1.31 & 66 & NA \\
\hline $\operatorname{IgAN}$ & IgAN7 (P) & M & 31 & 150 & 100 & 1.10 & 83 & 3.00 \\
\hline IgAN & IgAN8 (P) & M & 15 & 120 & 60 & 0.90 & 117 & 0.80 \\
\hline IgAN & IgAN9 (P) & $\mathrm{F}$ & 33 & 120 & 80 & 1.50 & 43 & 0.49 \\
\hline IgAN & IgAN10 (P) & M & 39 & NA & NA & 1.47 & 57 & 1.00 \\
\hline $\operatorname{IgAN}$ & IgAN11 (P) & M & 19 & 140 & 70 & 0.79 & 134 & 4.00 \\
\hline IgAN & IgAN12 (P) & $\mathrm{M}$ & 37 & 130 & 90 & 1.00 & 89 & 1.30 \\
\hline IgAN & IgAN13 (P) & $\mathrm{F}$ & 50 & 160 & 90 & 0.90 & 70 & 1.92 \\
\hline $\operatorname{Ig} A N$ & IgAN14 (P) & M & 36 & 150 & 80 & 4.50 & 16 & 3.80 \\
\hline IgAN & IgAN15 (P) & M & 49 & 160 & 90 & 0.90 & 95 & 10.00 \\
\hline Mean $\pm S D$ & & & $34 \pm 11$ & & & $1.3 \pm 0.9$ & $83 \pm 33$ & $2.2 \pm 2.7$ \\
\hline \multicolumn{9}{|l|}{ Controls } \\
\hline LD & LD1 (P) & $\mathrm{F}$ & 35 & NA & NA & $<1.0$ & $>60$ & no \\
\hline LD & LD2 (P) & $\mathrm{F}$ & 56 & NA & NA & $<1.0$ & $>60$ & no \\
\hline LD & LD3 $(P)$ & $M$ & 41 & NA & NA & $<1.0$ & $>60$ & no \\
\hline LD & LD4 (P) & M & 62 & NA & NA & $<1.0$ & $>60$ & no \\
\hline LD & LD5 (P) & $\mathrm{M}$ & 27 & NA & NA & $<1.0$ & $>60$ & no \\
\hline LD & LD6 (P) & NA & NA & NA & NA & $<1.0$ & $>60$ & no \\
\hline Mean $\pm \mathrm{SD}$ & & & $44 \pm 15$ & & & $<1.0$ & $>60$ & no \\
\hline
\end{tabular}

As controls we used tumor-free tissue from tumor nephrectomy specimens (TN) for the microarray experiments and biopsy specimens from living donor kidneys (LD) for the confirmational real-time RT-PCR experiments. Patients were analyzed by oligonucleotide array (A)-based gene expression profiling [NSC $(\mathrm{A}): n=14$, controls $(\mathrm{TN}): n=4]$ and real-time RT-PCR (P) [NSC (P): $n=13$, FSGS $(\mathrm{P}): n=18, \operatorname{IgAN}(\mathrm{P}): n=15, \mathrm{MCD}(\mathrm{P}): n=12$, controls (LD): $n=6]$. The patients' sex is given as male (M) or female (F). BP, blood pressure; eGFR, glomerular filtration rate (estimated according to the Modification of Diet in Renal Disease formula); NA, not available.

Gene Ontology (GO) terms associated with a given gene list. The significance determination of GO terms in DAVID is based on the Expression Analysis Systematic Explorer, a variant of one-tailed Fisher exact probability. ${ }^{28}$ For DAVID analyses, a $P$ value of 0.05 was used as standard cutoff level.

\section{Immunohistological Analysis}

HIF $1 \alpha$ staining was performed on biopsy specimens from an independent group of 9 patients with NSC and 5 controls (healthy tissue from TN), and CXCR4 staining was performed on biopsy specimens from an independent group of 15 patients with NSC and 5 controls (TN). Costaining was done on biopsy samples from 2 patients with NSC ( 3 and 11 glomeruli), 2 controls (TN, >20 glomeruli), and 4 patients with FSGS (10 to 34 glomeruli), one of these with a documented NPHS2 mutation. The following antibodies were used: a rabbit polyclonal antibody to CXCR4 (ab2074, Abcam, Eching, Germany) and monoclonal IgG2b against HIF1 $\alpha$ (NB 100-105, Novus Biologicals, Littleton, CO). For costaining, HIF was documented with the tyramide signal amplification system (TSATM Fluorescence System, NEN Life Science Products, Boston, MA). CXCR4 was then visualized by indirect immunofluorescence with an anti-rabbit antibody (AF488, 1:200, Invitrogen, Paisley, UK). Nuclei were stained by the DNA interactive agent DRAQ5TM (Alexis-Axxora, Lörrach, Germany). The staining shown is from a representative sample. The findings for CXCR4 and HIF1 $\alpha$ staining in glomerular podocytes that we report were globally present but showed focal accentuation.

For chemokine (C-X-C motif) ligand 12 (CXCL12; also called SDF-1), immunohistochemical analysis was performed as described previously. ${ }^{29}$ The primary antibody was a mouse anti-human CXCL12 (clone 79018, R\&D Systems, Minneapolis, MN). Immunohistochemical analysis was performed on normal areas collected from TNs $(n=3)$ and biopsy specimens from patients with NSC $(n=3)$. Replacement of the primary antibody by diluent served as a negative control.

\section{Cell Culture Experiments with Hypoxia}

We used established cell lines of immortalized murine $\left(\mathrm{K} \mathrm{PF}^{30}\right)$ and human podocytes (A $[\mathrm{h} 63]^{31}$ and $\mathrm{B}$ $\left.[A B 81]^{32}\right) . K 5 P 5, h 63$, and AB81 cells were cultured as given in the respective references. Normoxia was defined as $20 \% \mathrm{O}_{2}$ in the gas phase, and hypoxia constituted 2.0 and $0.2 \% \mathrm{O}_{2}$, respectively. For oxygen titration, cell cul- 
tures were distributed into incubators (Binder, Tuttlingen, Germany) with different oxygen concentrations (2.0 and $20 \% \mathrm{O}_{2}$ ) or were placed in a hypoxia incubator $\left(\mathrm{In} \mathrm{Vivo}_{2}\right.$ Hypoxia Workstation 400, Ruskinn Technology, Guiseley, UK, flushed with gas $\left[0.2 \% \mathrm{O}_{2}, 5 \% \mathrm{CO}_{2}\right.$, and $\left.94.8 \% \mathrm{~N}_{2}\right]$ ) and simultaneously cultured for the indicated time periods. Cells were analyzed at 4 hours for $\mathrm{HIF} 1 \alpha$, at 24 hours for HIF2 $\alpha$ Western blot analysis, and at 24 hours for mRNA expression analysis, respectively. Total cellular RNA was extracted using the Qiagen RNeasy kit (Qiagen, Hombrechtikon, Switzerland). The mRNA expression was analyzed by real-time RT-PCR.

\section{Western Blot}

For HIF1 $\alpha$ detection, cultured glomerular epithelial cells ${ }^{30,32}$ were harvested with lysis buffer $(10 \mathrm{mmol} / \mathrm{L}$ Tris- $\mathrm{HCl}[\mathrm{pH}$ 8.0], 0.1\% Nonidet P-40, $400 \mathrm{mmol} / \mathrm{L} \mathrm{NaCl}$, $1 \mathrm{mmol} / \mathrm{L}$ EDTA $[\mathrm{pH} 8.0], 1 \mathrm{mmol} / \mathrm{L}$ dithiothreitol, 1 $\mathrm{mmol} / \mathrm{L}$ phenylmethylsulfonyl fluoride, and Complete Protease Inhibitor Cocktail [Roche, Mannheim, Germany]). For HIF2 $\alpha$ detection, glomerular epithelial cells ${ }^{30,32}$ were harvested with a lysis buffer containing $8 \mathrm{M}$ urea (10 $\mathrm{mmol} / \mathrm{L}$ Tris- $\mathrm{HCl}$ [pH 6.8], $1 \% \mathrm{SDS}, 5 \mathrm{mmol} / \mathrm{L}$ dithiothreitol, $10 \%$ glycerol, $8 \mathrm{M}$ urea, $0.5 \mathrm{mmol} / \mathrm{L}$ phenylmethylsulfonyl fluoride, and Complete Protease Inhibitor Cocktail). The protein concentrations were determined by the Bradford method (Bio-Rad Laboratories, Hercules, CA). Extracted proteins were boiled in loading buffer for 5 minutes, resolved by $10 \%$ SDS-polyacrylamide gel electrophoreses under reducing conditions, and transferred to an Immobilon-P membrane (Millipore, Eschborn, Germany). Equal loading and transfer efficiencies were verified by staining with $2 \%$ Ponceau S. Membranes were blocked overnight with Tris-buffered saline/5\% fat-free skim milk and then incubated with a monoclonal mouse antibody raised against human $\mathrm{HIF} 1 \alpha$ (BD Transduction Laboratories, Lexington, $\mathrm{KY}$ ) diluted $1: 1000$ overnight at $4^{\circ} \mathrm{C}$ and rinsed with Tris-buffered saline containing $0.1 \%$ Tween 20. Immunoblotting for HIF1 $\alpha$ in murine podocytes was performed using polyclonal rabbit anti-HIF1 $\alpha$ antibody (1:200, overnight at $4^{\circ} \mathrm{C}$, Novus Biologicals). HIF2 $\alpha$ was detected using a polyclonal rabbit anti-HIF2 $\alpha$ antibody (1:200, overnight at $4^{\circ} \mathrm{C}$, Novus Biologicals).

For detection, a horseradish peroxidase-linked antimouse IgG antibody (1:2000, 1 hour at room temperature, DAKO, Glostrup, Denmark) and enhanced chemiluminescence substrate (PerkinElmer Life and Analytical Sciences, Waltham, MA) were used. Membranes were also probed with anti- $\beta$-actin antibody (A 5316, 1:5000, Sigma-Aldrich, Munich, Germany) as an internal loading control.

\section{In Vitro "Wound Healing" Assay}

In confluent cell monolayers on collagen-coated six-well plates, a scratch ("wound") was created with a sterile pipette tip. Cells were then incubated for 22 hours with either blocking rabbit anti-rat CXCR4 antibody $(5 \mu \mathrm{g} / \mathrm{ml}$, Torrey Pines Biolabs, East Orange, NJ), which has been shown to be effective in mice, ${ }^{8}$ or rabbit immunoglobulin IgG $(5 \mu \mathrm{g} / \mathrm{ml}$, R\&D Systems). At 0 hours and after 22 hours, the width of the scratch was measured at the same 10 to 12 points per well in a blinded fashion ( $n=12$ for each condition). The extent of wound healing is given as a percentage of the original width (1 - mean of measured distances at 22 hours/mean of measured distances at 0 hours).

\section{Quantitative Real-Time RT-PCR}

For studies using biopsy samples, reverse transcription and real-time RT-PCR were performed as reported earlier. ${ }^{33}$ Predeveloped TagMan reagents were used for human fibronectin 1 (FN1, NM_002026), human lysyl oxidase-like 2 (LOXL2, NM_002318.2), and the housekeeper genes 18S rRNA, GAPDH, and $\beta$-actin (Applied Biosystems, Foster City, CA). The following oligonucleotide primers (300 $\mathrm{nmol} / \mathrm{L})$ and probe $(100 \mathrm{nmol} / \mathrm{L})$ were used for human CXCR4 (NM_003467.2), sense primer 5'-GGCCGACCTCCTCTTTGTC-3', antisense primer 5'-CAAAGTACCAGTTTGCCACGG-3', and fluorescence labeled probe (FAM) 5'ACGCTTCCCTTCTGGGCAGTTGATG-3'; and for CXCL12 (NM_199168), sense primer 5'-ACCGCGCTCTGCCTCA$3^{\prime}$, antisense primer 5'-CATGGCTTTCGAAGAATCGG-3', and fluorescence labeled probe (FAM) 5'-TCAGCCTGAGCTACAGATGCCCATGC-3'. The expression of candidate genes was normalized to three reference genes, 18S rRNA, hGAPDH, and $\beta$-actin, giving similar results. Data shown are normalized to $18 \mathrm{~S}$ rRNA, and target gene expression in the control cohort is set as 1. The mRNA expression was analyzed by standard curve quantification.

For in vitro studies, reverse transcription was performed as described above. Predeveloped TaqMan reagents were used for human CXCR4 (NM_003467.2) and for the reference gene $18 \mathrm{~S}$ rRNA (Applied Biosystems). For human and murine vascular endothelial growth factor A (VEGFA and Vegfa, respectively) and murine $\mathrm{Cxcr}$, the following oligonucleotide primers (300 nmol/L) and probes (100 nmol/L) were used: for human VEGFA (NM_003376), sense primer 5'-GCCTTGCTGCTCTACCTCCAC-3', antisense primer 5'ATGATTCTGCCCTCCTCCTTCT-3', and fluorescence labeled probe (FAM) 5'-AAGTGGTCCCAGGCTGCACCCAT-3'; for murine Vegfa (NM_001025250.3), sense primer 5'-GCTGTGCAGGCTGCTGTAAC-3', antisense primer 5'TGATGTTGCTCTCTGACGTGG-3', and fluorescence labeled probe (FAM) 5'-ATGAAGCCCTGGAGTGCGTGCC3'; and for murine CxCr4 (NM_009911.3), sense primer 5'-TGGAACCGATCAGTGTGAGTATATA-3', antisense primer 5'-GGTGGGCAGGAAGATCCTATT-3', and fluorescence labeled probe (FAM) 5'-CTGCTTCCGGGATGAAAACGTCCATT-3'. The expression of candidate genes was normalized to $18 \mathrm{~S}$ rRNA and analyzed by the $\Delta \Delta \mathrm{Ct}$ method.

\section{Statistics}

Experimental data are given as mean \pm SD. Statistical analysis was performed using the Mann-Whitney $U$ test and the Welch and Games-Howell test (SPSS 14.0, SPSS, 
Chicago, IL). $P$ and $q$ values $<0.05$ were considered to indicate statistically significant differences.

\section{Results}

\section{Glomerular Expression of Hypoxia-Regulated Genes Is Altered in NSC}

Gene expression profiling was performed on isolated glomeruli to study alterations in gene transcript expression in NSC. In choosing the cohort to be examined, specific attention was paid to the histological criteria of NSC and clinical features. ${ }^{11-15}$ The clinical characteristics of the patients are provided in Table 1. Glomerular gene expression profiles yielded 14,762 probe sets with expression intensities above cutoff (see Materials and Methods). We used unsupervised clustering to visualize the probe sets in a dendrogram. Cluster dendrograms sort samples with the most similar gene expression profiles together with the shortest branches. Clustering all 14,762 probe sets above cutoff resulted in clear segregation of NSC from TN (Supplemental Figure S1, see http://ajp.amjpathol.org). The comparison between controls and NSC resulted in 7,381 significantly altered probe sets (Supplemental Table S1, see http://ajp.amjpathol. org). These corresponded to roughly 5,711 genes, taking the limitations of the default Affymetrix probe set annotation into account. ${ }^{34}$

To test whether hypoxia-related biological processes previously reported to contribute to deterioration of renal function may be involved in NSC, the data were grouped according to their GO classification. ${ }^{1}$ The glomerular gene expression data demonstrated significant overrepresentation of GO terms of two biological processes potentially involved in hypoxia-related kidney damage: angiogenesis (eg, the GO terms "angiogenesis" [GO:0001525] and "vasculature development" [GO:0001944]) (Supplemental Table S2, see http://ajp.amjpathol.org) and inflammation (eg, GO terms "immune response" [GO:0006955] and "inflammatory response" [GO:0006954]) (Supplemental Table S3, see http://ajp.amjpathol.org). A third process, renal fibrosis, has recently been discussed as being controlled by HIF.1,3 Because a corresponding GO term does not exist, we used a literature-based list of genes potentially involved in renal fibrosis. ${ }^{35-38}$ Of 84 fibrosis-related genes derived from the literature, 83 were represented on the HG-U133A array. Of these, 73 genes showed mRNA expression above the cutoff in the expression array analysis of the glomeruli from NSC biopsy specimens. Of these, $42(58 \%)$ were found to be significantly altered in NSC compared with controls (Supplemental Table S4, see http://ajp.amjpathol. org). In summary, GO analyses of the microarray data from glomeruli with NSC support the idea of hypoxiaassociated processes being involved in the development of renal disease.

These initial results prompted us to further evaluate the potential role of hypoxia-regulated gene expression in glomeruli from NSC biopsy specimens. A literaturebased list of previously reported HIF target genes was generated. ${ }^{39,40}$ From a total of $554 \mathrm{HIF}$ target genes, 542 were represented on the HG-U133A array and 476 showed mRNA expression above cutoff. Expression of $290(61 \%)$ of these genes was significantly altered in glomeruli with NSC compared with controls (Supplemental Table S5, see http://ajp.amjpathol.org). This number is higher than that observed in patients with FSGS, in whom expression of only $23 \%$ of the HIF target genes was found to be changed ( $n=13$, unpublished data). Because $\mathrm{HIF} \alpha$ subunits are regulated mainly at the post-translational level, it was not surprising that HIF1A mRNA itself was not significantly altered in glomeruli with NSC (HIF1A, probe set 200989_at, fold change 0.96, NS). HIF2A mRNA was significantly increased (EPAS1, probe set 200879_s_at, fold change 1.25, $q=0.05$ and 200878_at, fold change 1.57, $q<0.01$ ). To further evaluate our hypothesis that hypoxia may play a significant pathophysiological role in NSC, we examined whether expression of HIF-regulated genes might segregate glomerular gene expression in NSC biopsy specimens from that in controls. We used unsupervised clustering to visualize the 476 HIF target genes above cutoff in a dendrogram. This cluster dendrogram of HIF target genes segregated NSC from controls with two distinct branches being identified: one corresponding to the NSC group and the other one to the TN control group (Figure 1). No association of HIF target gene expression with clinical parameters (renal function or proteinuria) or antihypertensive treatment with or without blockade of the renin angiotensin system was observed nor was there a correlation with the histological degree of glomerular scarring on this limited number of patients. Of $25 \mathrm{HIF}$ targets with relevance to renal function, reported by Haase et al, ${ }^{5} 20$ genes showed mRNA expression above cutoff. Expression of $16(80 \%)$ of these was significantly changed in glomeruli with NSC compared with controls (Table 2). Among the HIF targets, which were significantly more abundant in glomeruli with NSC (Table 2 and Supplemental Table S5, see http://ajp.amjpathol.org), we found genes representing prominent hypoxia-modulated biological processes such as angiogenesis, fibrosis, and inflammation. VEGFA and its receptor FMS-like tyrosine kinase 1 (FLT1), both with significantly increased transcript levels in glomeruli with NSC, are examples of genes involved in the first process. For early as well as late stages of fibrosis the following genes are prominent indicators: TIMP1 (tissue inhibitor of metalloproteinase 1), SERPINE1 (serpin peptidase inhibitor, clade E, member 1 , also called plasminogen activator inhibitor type 1$),{ }^{4}$ LOX (lysyl oxidase), and LOXL2 (lysyl oxidase-like 2). ${ }^{3}$ Fibronectin (FN1) mRNA, also shown to be up-regulated under hypoxic conditions, ${ }^{41,42}$ was strongly increased in glomeruli with NSC. Furthermore, mRNA expression for several collagen $\alpha$-chains was increased in NSC glomeruli, including the reportedly hypoxia-inducible genes COL1A2, COL4A1, and COL4A2. ${ }^{4,39}$ Interestingly, only the embryonic (COL4A1 and COL4A2) and not the mature isoforms of collagen type 4 (COL4A3, COL4A4, and COL4A5) were found to be significantly altered in NSC glomeruli (Supplemental Table S4, see http://ajp.amjpathol.org). ${ }^{43} \mathrm{Fi}$ nally, among the above processes inflammation emerged as a prominent one in NSC (Supplemental Table S3, see 

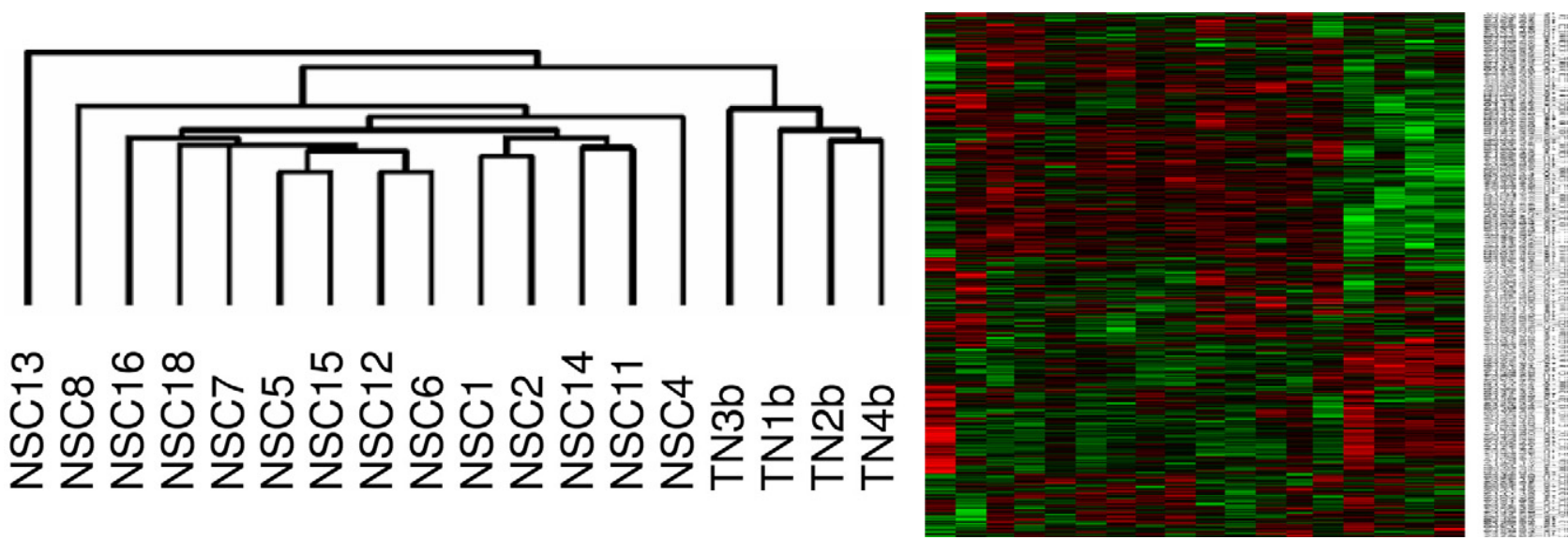

Figure 1. Cluster of HIF target genes in NSC. Unbiased and unsupervised clustering was used to visualize the expressed HIF target genes in a dendrogram. Cluster dendrograms group the patients with the most similar gene expression profiles. The length of the branches represents the dissimilarity. Probe set abundance is displayed on a red-green color scale, with red indicating expression above and green below the mean. This cluster dendrogram uses the HIF target genes to segregate NSC from the healthy controls. Two distinct branches could be identified: one corresponding to the NSC group and the other one to the TN group.

http://ajp.amjpathol.org). In line with this finding, the chemokine receptor CXCR4 was one of the most strongly increased HIF target genes in NSC glomeruli.

\section{Glomerular Induction of CXCR4 mRNA Is Found in NSC, but Not in Other Common \\ Glomerulopathies}

From the above-mentioned significantly altered HIF target genes we selected LOXL2, FN1, and CXCR4 for further confirmatory analysis. The glomerular mRNA expression was determined by real-time RT-PCR in an independent cohort of patients with NSC and patients with other glomerulopathies such as FSGS, IgAN, and MCD. Pretransplant allograft biopsy specimens from LDs served as healthy controls (Table 1). A significant induction of LOXL2 mRNA (2.6 \pm 1.7-fold, $P<0.01)$ and FN1 mRNA $(5.5 \pm 3.7$-fold, $P<0.01)$ was found in glomeruli with NSC compared with controls. LOXL2 and FN1 mRNA were not found to be consistently induced in glomeruli from patients with FSGS, IgAN, and MCD (LOXL2: FSGS $1.1 \pm 0.4$, NS, IgAN $1.4 \pm 0.9$, NS, and MCD $0.9 \pm 1.0$ NS, compared with controls; FN1: FSGS $1.2 \pm 1.6, \mathrm{NS}$, IgAN $0.9 \pm 1.1$, MS, and MCD $0.3 \pm 0.2$, NS, compared with controls) (Figure 2, A and B). The mRNA for CXCR4, one of the most strongly altered HIF target templates in our microarray data set, was also found to be induced in glomeruli of an independent cohort of patients with NSC, but not in those with FSGS, MCD, or IgAN (NSC $2.0 \pm 1.1$, $P<0.05$; FSGS $0.6 \pm 0.4$, NS; IgAN $0.4 \pm 0.2, P<0.05$; and MCD $0.6 \pm 0.5$, NS, compared with controls) (Figure 2C). Expression of the known ligand of CXCR4, ie, CXCL12, was not found to be significantly altered in the glomerular microarray data. This result was again confirmed by real-time RT-PCR, which demonstrated only a nonsignificant trend for CXCL12 mRNA induction in NSC (NSC $3.9 \pm 4.8$, NS; FSGS $1.4 \pm 1.5$, NS; IgAN $0.9 \pm 0.9$, NS; and MCD $1.8 \pm 1.9, \mathrm{NS}$ ). In summary, the real-time RT-PCR studies on independent patient cohorts supported the microarray data and confirmed the glomerular induction of LOXL2, FN1, and CXCR4 mRNA seen on the microarray as potential contributors to hypoxia-induced pathomechanisms in NSC.

\section{HIF1 $\alpha$ Shows Nuclear Localization in CXCR4-Positive Podocytes of NSC Biopsy Specimens}

To demonstrate the glomerular cell type expressing CXCR4 in NSC, immunohistological analysis was performed on additional biopsy specimens to further study the expression of CXCR4. In NSC biopsy specimens, the CXCR4 protein could be localized to glomerular epithelial cells in all glomeruli with a prominent increase in fluorescence intensity compared with the faint staining for CXCR4 in control kidneys (Figure 3, A-C). As was expected, interstitial mononuclear cells also stained positive for CXCR4 (not shown).

To evaluate whether the CXCR4 protein expression in podocytes of NSC biopsy specimens was associated with HIF1 $\alpha$ activation as a general marker of hypoxiaassociated transcriptional activation, double staining for both molecules was performed. A faint cytoplasmic staining for HIF1 $\alpha$ was occasionally seen in cells of control biopsy specimens. In marked contrast, a robust nuclear HIF1 $\alpha$ staining was apparent in podocytes from NSC biopsy specimens and colocalized with staining for CXCR4 (Figure 3, A and B). Because HIF1 $\alpha$ is translocated from the cytosol to the nucleus on activation, the localization may indicate transcriptional activity of HIF in these cells. ${ }^{5}$ Occasionally tubular epithelial cells showed also a nuclear staining pattern for $\operatorname{HIF} 1 \alpha$. These cells demonstrated no concomitant CXCR4 staining. In biopsy specimens from patients with the main diagnosis of FSGS, glomerular epithelial cells stained also positive for CXCR4 but with a restrained and heterogeneous nuclear HIF1 $\alpha$ positivity. This result is in line with the microarray data reported above, which indicate a more pronounced hypoxia-associated gene regulation in NSC glomeruli than in FSGS glomeruli. 
Table 2. Regulation of HIF Target Genes with Relevance to Renal Function

\begin{tabular}{|c|c|c|c|c|}
\hline Probe set & Gene symbol (HUGO) & Gene name (from Affymetrix HG-U133A-20080318) & Fold change & $q$ value $(\%)$ \\
\hline 200966_x_at & $A L D O A$ & Aldolase A, fructose-bisphosphate & 1.12 & 4.87 \\
\hline 214687_x_at & $A L D O A$ & Aldolase $A$, fructose-bisphosphate & 1.13 & 2.27 \\
\hline 201849_at & BNIP3 & BCL2/adenovirus E1B 19kDa interacting protein 3 & 0.74 & 0.73 \\
\hline 201848_s_at & BNIP3 & BCL2/adenovirus E1B $19 \mathrm{kDa}$ interacting protein 3 & 0.80 & 4.87 \\
\hline 205199_at & CA9 & Carbonic anhydrase IX & 0.83 & 0.88 \\
\hline 211919_s_at & CXCR4 & Chemokine (C-X-C motif) receptor 4 & 2.37 & 0.08 \\
\hline 209201_x_at & CXCR4 & Chemokine (C-X-C motif) receptor 4 & 2.41 & 0.03 \\
\hline 217028_at & CXCR4 & Chemokine (C-X-C motif) receptor 4 & 4.23 & 0.03 \\
\hline 209101_at & CTGF & Connective tissue growth factor & 0.88 & 18.58 \\
\hline 218995_s_at & EDN1 & Endothelin 1 & 0.94 & 22.72 \\
\hline 201231_s_at & ENO1 & Enolase 1, (alpha) & 0.89 & 19.75 \\
\hline 217294_s_at & ENO1 & Enolase 1, (alpha) & 1.21 & 4.87 \\
\hline 217254_s_at & EPO & Erythropoietin & $\mathrm{BC}$ & $\mathrm{BC}$ \\
\hline 207257_at & $E P O$ & Erythropoietin & $\mathrm{BC}$ & $\mathrm{BC}$ \\
\hline 222033_s_at & FLT1 & Fms-related tyrosine kinase 1 & 1.74 & 0.03 \\
\hline 210287_s_at & FLT1 & Fms-related tyrosine kinase 1 & $\mathrm{BC}$ & $\mathrm{BC}$ \\
\hline 204406_at & FLT1 & Fms-related tyrosine kinase 1 & $\mathrm{BC}$ & $\mathrm{BC}$ \\
\hline 203665_at & HMOX1 & Heme oxygenase (decycling) 1 & 0.57 & 0.73 \\
\hline 202934_at & $H K 2$ & Hexokinase 2 & 1.33 & 4.87 \\
\hline 222305_at & HK2 & Hexokinase 2 & $\mathrm{BC}$ & $\mathrm{BC}$ \\
\hline 205302_at & IGFBP1 & Insulin-like growth factor binding protein 1 & $\mathrm{BC}$ & $\mathrm{BC}$ \\
\hline 200650_s_at & LDHA & Lactate dehydrogenase A & $\mathrm{BC}$ & $\mathrm{BC}$ \\
\hline 203510_at & MET & Met proto-oncogene & 0.62 & 0.73 \\
\hline 211599_x_at & MET & Met proto-oncogene & 0.84 & 1.58 \\
\hline 213807_x_at & MET & Met proto-oncogene & 0.84 & 0.73 \\
\hline 213816_s_at & MET & Met proto-oncogene & $\mathrm{BC}$ & $\mathrm{BC}$ \\
\hline 209957_s_at & NPPA & Natriuretic peptide precursor A & 0.78 & 0.06 \\
\hline 210037_s_at & NOS2A & Nitric oxide synthase $2 \mathrm{~A}$ & $\mathrm{BC}$ & $\mathrm{BC}$ \\
\hline 205581_s_at & NOS3 & Nitric oxide synthase 3 & $\mathrm{BC}$ & $\mathrm{BC}$ \\
\hline 200738_s_at & PGK1 & Phosphoglycerate kinase 1 & 1.03 & 19.75 \\
\hline 200737_at & PGK1 & Phosphoglycerate kinase 1 & 1.18 & 4.87 \\
\hline 217383_at & PGK1 & Phosphoglycerate kinase 1 & 1.24 & 4.87 \\
\hline 217356_s_at & PGK1 & Phosphoglycerate kinase 1 & $\mathrm{BC}$ & $\mathrm{BC}$ \\
\hline 200725_x_at & RPL10 & Ribosomal protein L10 & 1.05 & 10.75 \\
\hline 200724_at & RPL10 & Ribosomal protein L10 & 1.09 & 10.75 \\
\hline 221989_at & RPL10 & Ribosomal protein L10 & 1.33 & 1.58 \\
\hline 217680_x_at & RPL10 & Ribosomal protein L10 & $\mathrm{BC}$ & $\mathrm{BC}$ \\
\hline 202628_s_at & SERPINE1 & Serpin peptidase inhibitor & 1.20 & 8.92 \\
\hline 202627_s_at & SERPINE1 & Serpin peptidase inhibitor, clade $\mathrm{E}$ & 1.26 & 1.14 \\
\hline 201250_s_at & SLC2A1 & Solute carrier family 2 , member 1 & 0.76 & 0.07 \\
\hline 201249_at & SLC2A1 & Solute carrier family 2 , member 1 & $\mathrm{BC}$ & $\mathrm{BC}$ \\
\hline 201666_at & TIMP1 & TIMP metallopeptidase inhibitor 1 & 1.65 & 0.10 \\
\hline 214064_at & TF & Transferrin & $\mathrm{BC}$ & $\mathrm{BC}$ \\
\hline 214063_s_at & TF & Transferrin & $\mathrm{BC}$ & $\mathrm{BC}$ \\
\hline 203400_s_at & TF & Transferrin & $\mathrm{BC}$ & $\mathrm{BC}$ \\
\hline 220109_at & TF & Transferrin & $\mathrm{BC}$ & $\mathrm{BC}$ \\
\hline 208691_at & TFRC & Transferrin receptor /// transferrin receptor & 0.81 & 10.75 \\
\hline 207332_s_at & TFRC & Transferrin receptor /// transferrin receptor & 0.85 & 12.73 \\
\hline 210512_s_at & VEGFA & Vascular endothelial growth factor & 1.06 & 17.38 \\
\hline 212171_x_at & VEGFA & Vascular endothelial growth factor & 1.11 & 14.49 \\
\hline 211527_x_at & VEGFA & Vascular endothelial growth factor & 1.31 & 4.87 \\
\hline 210513_s_at & VEGFA & Vascular endothelial growth factor & 1.38 & 0.06 \\
\hline
\end{tabular}

Twenty-five of 25 selected HIF targets with relevance to renal function derived from the literature were represented on the HG-U133A array. Twenty of these genes showed mRNA expression above cutoff on the arrays. Of these 20 expressed mRNAs, $16(80 \%)$ were significantly regulated in glomeruli from NSC biopsy samples compared with controls (TN). ${ }^{5}$ The fold change indicates the expression of each gene in nephrosclerosis (NSC) glomeruli compared with controls, ie, a fold change of 1.75 refers to an induction of $75 \%$ in NSC. BC, below cutoff, see Materials and Methods for further detail.

CXCL12, the corresponding ligand of CXCR4, was also found to be expressed in podocytes of NSC biopsy specimens as well as in control tissue (Figure 4). In addition, CXCL12 expression was seen on some tubular epithelial cells and on endothelial cells of larger veins and arteries. The constitutive expression was consistent with the mRNA expression data, indicating no CXCL12 mRNA induction in NSC.

\section{Hypoxia Induces HIF $\alpha$ Protein and CXCR4 mRNA in Podocytes in Vitro}

CXCR4 and nuclear HIF1 $\alpha$ colocalized to podocytes in double immunofluorescence staining. We therefore studied podocytes in vitro to define whether this might represent a functional association. We exposed podocyte cell lines $^{30-32}$ to hypoxic culture conditions. By Western blot, 

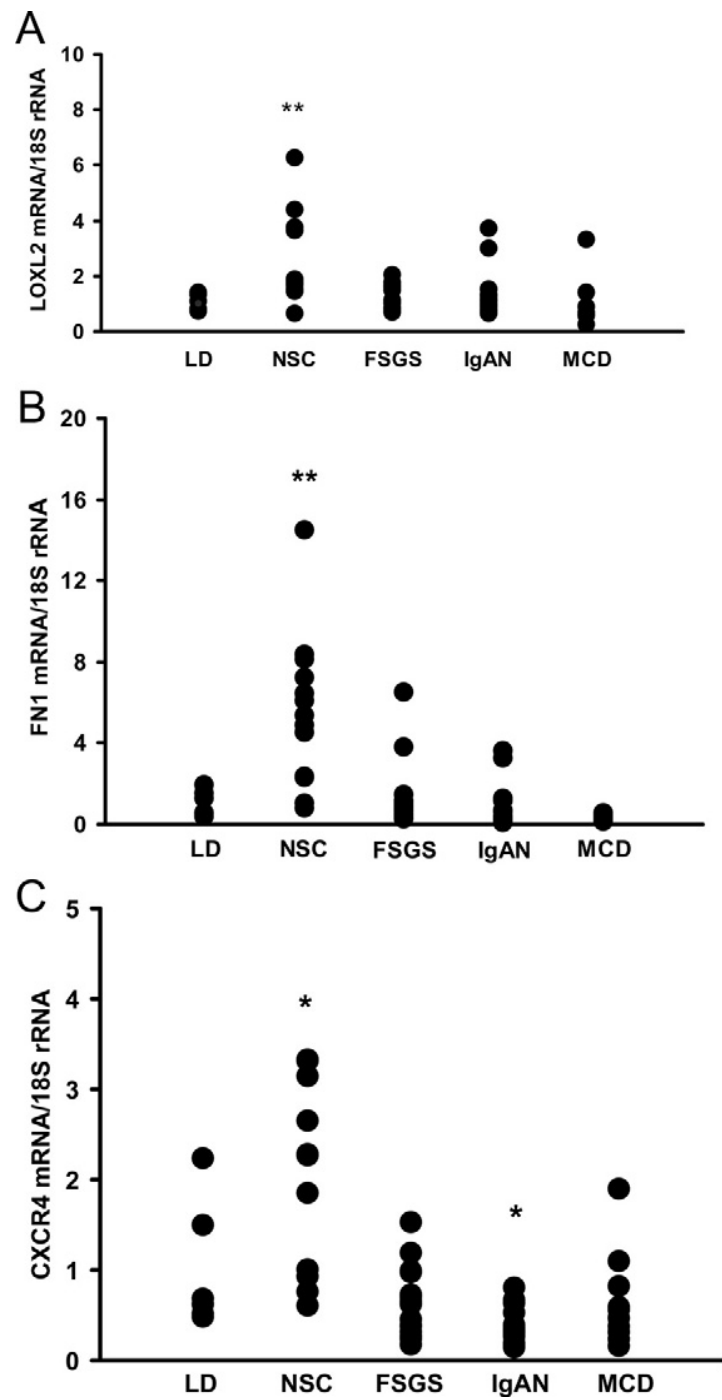

Figure 2. Confirmation of LOXL2, FN1, and CXCR4 mRNA expression in glomeruli with NSC and controls. A: LOXL2 mRNA measured by RT-PCR is induced in glomeruli from NSC biopsy specimens. LOXL2 mRNA showed increased expression by quantitative RT-PCR in glomeruli from an independent group of NSC biopsy specimens $(n=13)$. Values were normalized to pretransplant LD control biopsy specimens $(n=6)$ and the housekeeper gene $18 S$ rRNA. In FSGS, IgAN, and MCD, LOXL2 mRNA was not significantly different compared with that in living donor (LD) controls. ** $P<0.01$ compared with controls. B: FN1 mRNA is overexpressed in glomeruli from NSC biopsy specimens. Same biopsy cohorts as mentioned in $\mathbf{A} .{ }^{* * *} P<0.01$ compared with controls (LD). C: CXCR4 mRNA expression levels are higher in glomeruli from NSC biopsy specimens. Same biopsy cohorts as mentioned in A ${ }^{*} P<0.05$ compared with controls (LD). FSGS, focal segmental glomerusclerosis; IgAN, IgA nephropathy; MCD, minimal change disease.

we were able to demonstrate higher $\mathrm{HIF} 1 \alpha$ and $\mathrm{HIF} 2 \alpha$ protein levels under graded hypoxic conditions compared with normoxic controls (see Figure $5, A$ and $B,{ }^{32}$ for human podocytes; murine podocytes not shown). Hypoxic incubation conditions ( $0.2 \%$ and $2 \%$ oxygen) resulted in a significant increase in CXCR4/Cxcr4 mRNA in all podocyte cell lines tested compared with $20 \%$ oxygen concentration (Figure 6, Table 3). VEGFANegfa mRNA served as a positive control for a hypoxia-induced genes and also showed an induction under hypoxic conditions (Table 3).

As CXCR4 and CXCL12 were both found to be expressed by podocytes, we set out to study a functional
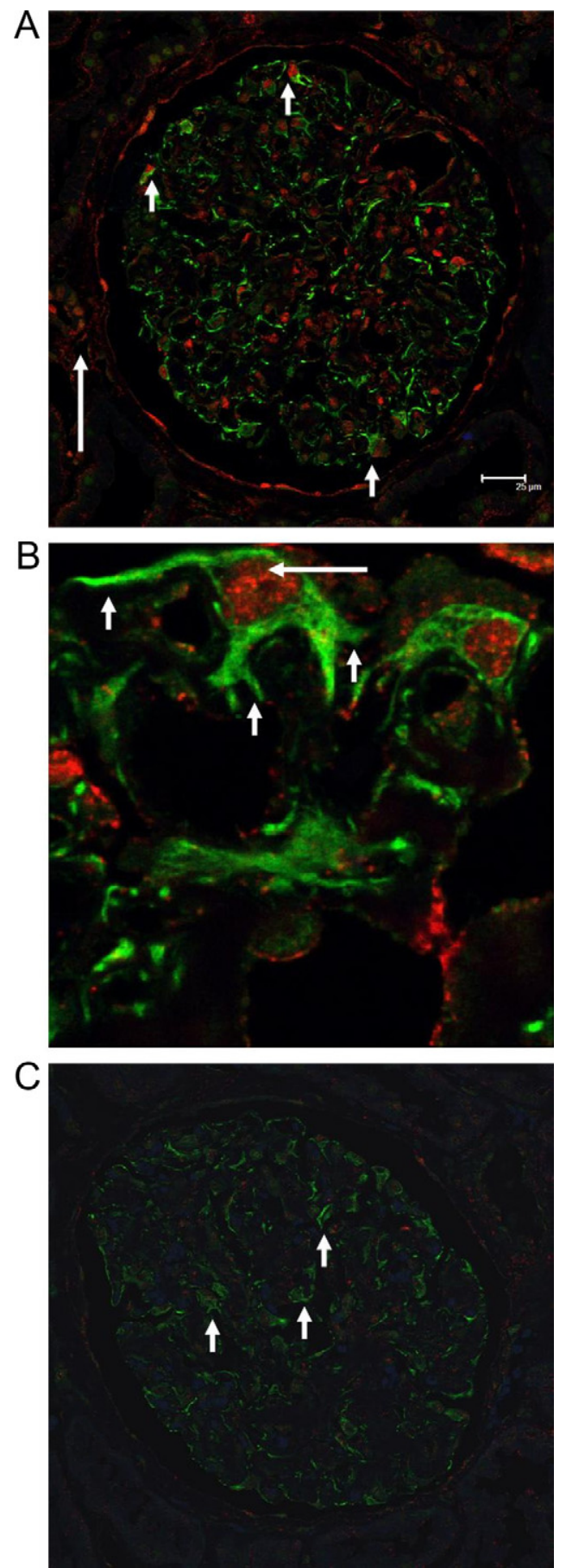

Figure 3. CXCR 4 and HIF $1 \alpha$ staining in NSC and controls. A: CXCR 4 and HIF1 $\alpha$ staining in glomeruli with NSC. CXCR4 (green staining) and HIF $1 \alpha$ (red staining) showed robust expression in podocytes of NSC (short arrows). As expected some tubular epithelial cells stained positive for HIF1 $\alpha$ (long arrow). Interstitial mononuclear cells also stained positive for CXCR4 (not shown). B: High magnification of CXCR4 and HIF1 $\alpha$ staining in NSC. Higher magnification of glomerular epithelial cells with surface staining for CXCR4 (short arrows) and nuclear staining for HIF1 $\alpha$ (long arrow) C: CXCR 4 and HIF $1 \alpha$ staining in glomeruli from controls. Healthy tissue from TN served as a control, with podocytes showing a faint green CXCR4 background staining (arrows) without any HIF $1 \alpha$ positivity.

role of this receptor/ligand system. Because CXCR4 is known to play a role in guidance of cell migration, we applied an in vitro scratch assay on cultured podocytes. In line with a functional relevance of CXCR4/CXCL12 in 


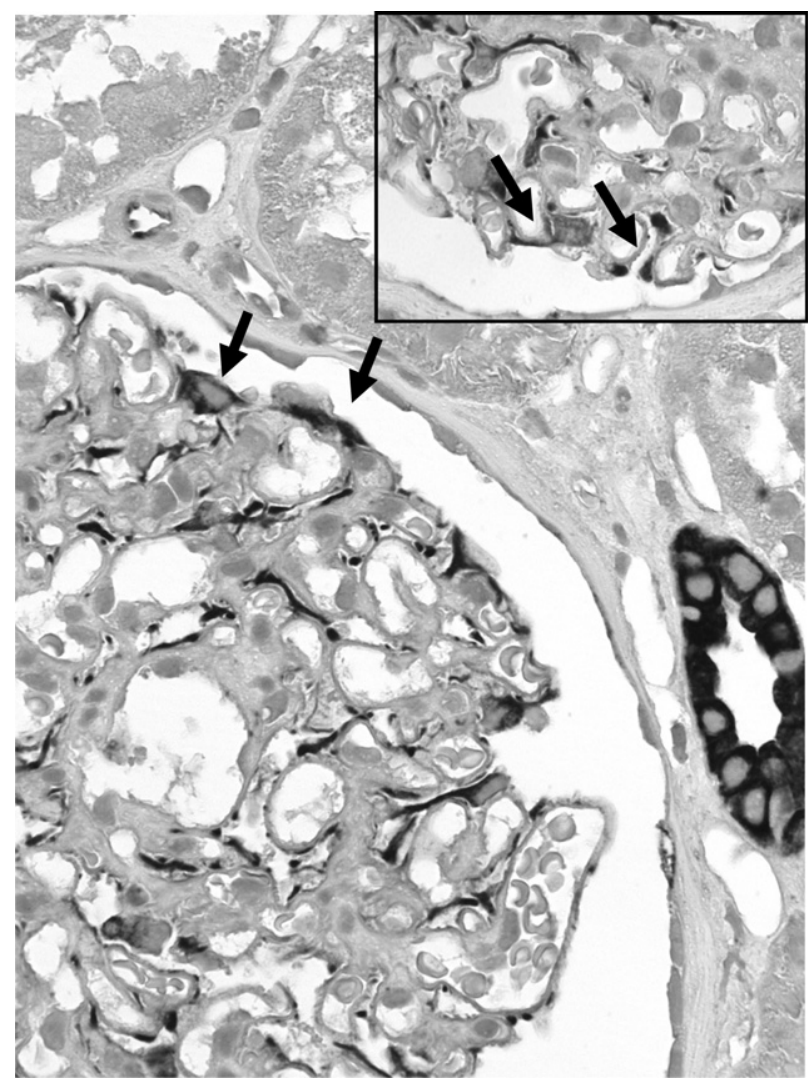

Figure 4. CXCL12 staining in glomeruli with NSC. CXCL12 was localized by immunohistochemical analysis in biopsy specimens from patients with NSC and controls. A prominent CXCL12 expression was found, in a pattern consistent with podocytes. Note the staining of cells on the outer surface of the glomerular basement membrane (arrows). Original magnification, $\times 400$. Inset: Higher magnification of CXCL12 staining of glomeruli with NSC confirmed expression by podocytes (arrows). Original magnification, $\times 1000$.

podocyte biology, a blocking CXCR4 antibody significantly impaired the extent of wound closure in these cells compared with control IgG (23 $\pm 6 \%$ versus $41 \pm 13 \%$, $P<0.01, n=12$ each) (Figure 7 ).

\section{Discussion}

The growing evidence for hypoxia as a modulator of progression of renal disease prompted us to examine its

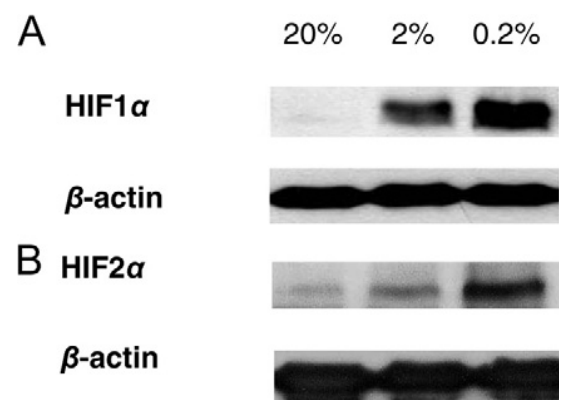

Figure 5. Hypoxia induces HIF $1 \alpha$ and HIF $2 \alpha$ protein in cultured podocytes A: By Western blot a dose-dependent induction of HIF1 $\alpha$ under graded hypoxic conditions $\left(0.2\right.$ and $\left.2 \% \mathrm{O}_{2}\right)$ was demonstrated in human podocytes $^{32}$ compared with normoxic time controls $\left(20 \% \mathrm{O}_{2}\right.$, at 4 hours). B: In addition, HIF $2 \alpha$ was found to be stabilized in human podocytes at 0.2 and $2 \%$ $\mathrm{O}_{2}$ compared with $20 \% \mathrm{O}_{2}$ (at 24 hours). $\beta$-Actin was used as loading control.

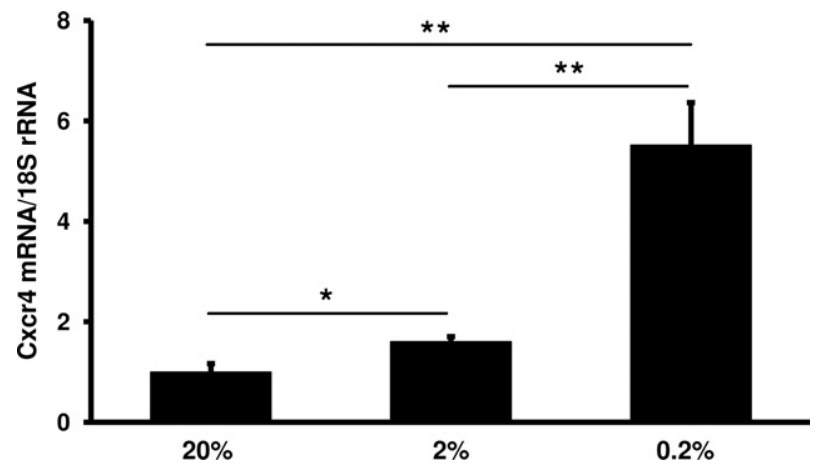

Figure 6. Hypoxia induces Cxcr4 mRNA in podocytes in vitro. In cultured murine podocytes, expression of Cxcr4 mRNA was increased after 24 hours at $0.2 \% \mathrm{O}_{2}$ compared with podocytes incubated at $2 \% \mathrm{O}_{2}$ after 24 hours and normoxic $\left(20 \% \mathrm{O}_{2}\right)$ controls $\left(n=4\right.$ each). ${ }^{*} P<0.05$, ${ }^{* *} P<0.01$, significant differences compared with $20 \% \mathrm{O}_{2} \cdot{ }^{* * *} P<0.01$, significant difference comparing 0.2 with $2 \% \mathrm{O}_{2}$. For expression data of CXCR 4 and VEGFA in human podocyte cell lines exposed to hypoxia, see Table 3.

potential role in human NSC. ${ }^{1}$ NSC represents an entity with a poorly understood pathogenesis, even though it is reported to be the second most common cause for endstage renal disease in the Western world. ${ }^{10}$ We found hypoxia-related genes to be clearly induced in glomeruli from patients with NSC. CXCR4, a known target of HIF, was significantly induced in NSC and could be localized to podocytes together with positive nuclear staining for HIF $1 \alpha$ as a general indicator for hypoxia-associated transcriptional activity.

The hypothesis-driven analysis of the gene expression data was focused on genes known to be regulated by HIF. ${ }^{5,39,40}$ Consistent with the hypothesis that hypoxia is an important factor in NSC, the majority of known HIF target genes were significantly altered in glomeruli from NSC biopsy specimens and segregated them from controls in the unsupervised cluster analysis. Prominent biological processes modulated by hypoxia are angiogenesis, fibrosis, and inflammation. In angiogenesis, VEGFA and its receptor FLT1, both significantly increased in NSC, play a central role (Table 2). VEGFA is an important growth, survival, and repair factor for glomerular capillaries. The induction of VEGFA in the glomeruli of the NSC cohort is consistent with previously reported expression of VEGF mRNA in podocytes in NSC ${ }^{44}$ and induction of VEGFA mRNA in cultured podocytes under hypoxia (Table 3). The finding of glomerular VEGFA and FLT1 induction in NSC biopsy specimens is in contrast to the reduced expression of VEGFA recently reported in human diabetic nephropathy both in glomeruli and in the tubulointerstitial compartment, indicating a different pathophysiological mechanism for glomerulosclerosis in NSC and diabetic nephropathy. ${ }^{33,45}$ HIF target genes involved in the accumulation of extracellular matrix and fibrosis were also found to be induced in glomeruli with NSC. This finding was confirmed by RT-PCR for FN1, for which HIF-independent regulatory mechanisms are also described, ${ }^{46}$ and for LOXL2. LOX, and LOXL2 are documented examples of genes involved in matrix remodeling by cross-linking of collagen fibers. They were recently reported to be induced in a murine model of hypoxia-induced tubulointerstitial fibrosis. ${ }^{3}$ Tubulointerstitial 
Table 3. Cxcr4/CXCR4 and Vegfa/VEGFA mRNA Expression under Hypoxic Conditions

\begin{tabular}{|c|c|c|c|}
\hline & $20 \% \mathrm{O}_{2}$ & $2 \% \mathrm{O}_{2}$ & $0.2 \% \mathrm{O}_{2}$ \\
\hline \multicolumn{4}{|l|}{ VegFa/VEGFA } \\
\hline Murine podocytes & $1.00 \pm 0.04$ & $1.22 \pm 0.08^{*}$ & $2.21 \pm 0.41^{* \neq}$ \\
\hline Human podocytes A & $1.00 \pm 0.36$ & $3.35 \pm 1.70(\mathrm{NS})$ & $11.97 \pm 1.35^{\neq \S}$ \\
\hline Human podocytes $B$ & $1.00 \pm 0.11$ & $1.36 \pm 0.31^{*}$ & $2.23 \pm 0.67^{\dagger \neq}$ \\
\hline \multicolumn{4}{|l|}{ Cxcr4/CXCR4 } \\
\hline Murine podocytes & $1.00 \pm 0.17$ & $1.60 \pm 0.10^{*}$ & $5.52 \pm 0.85^{\ddagger \S}$ \\
\hline Human podocytes A & $1.00 \pm 0.17$ & $9.98 \pm 3.29^{*}$ & $19.16 \pm 3.56^{\dagger \neq}$ \\
\hline Human podocytes B & $1.00 \pm 0.30$ & $1.29 \pm 0.35(\mathrm{NS})$ & $4.41 \pm 1.67^{\ddagger \S}$ \\
\hline
\end{tabular}

Expression of Cxcr4/CXCR4 and Vegfa/VEGFA mRNA in cultured murine (K5P5) and human podocytes (podocytes A [h63] and podocytes B [AB81]) after incubation for 24 hours at 0.2 and $2 \% \mathrm{O}_{2}$ compared with $20 \% \mathrm{O}_{2}(n=4$ each for $\mathrm{K} 5 \mathrm{P} 5$ and $\mathrm{h} 63$ and $n=8$ for AB81).

${ }^{*} P<0.05$, significant difference compared with $20 \% \mathrm{O}_{2}$

$+P<0.05$, significant difference comparing 0.2 with $2 \% \mathrm{O}_{2}$.

${ }^{\prime} P<0.01$, significant difference compared with $20 \% \mathrm{O}_{2}$

$\S P<0.01$, significant difference comparing 0.2 with $2 \% \mathrm{O}_{2}$.

LOXL2 mRNA was also found to be induced in various progressive human renal diseases including NSC. ${ }^{3}$ Our present data showing increased LOXL2 expression in glomeruli with NSC but not other glomerulopathies may indicate that this hypoxia-inducible enzyme is not only involved in progressive interstitial fibrosis but may also play a role in glomerulosclerosis in NSC. Besides these collagen-associated molecules increased mRNA expression for several collagen $\alpha$-chains, the known HIF target genes COL1A2, COL4A1, and COL4A2, was prominent in the NSC data set. ${ }^{39}$ We observed significant increases only for the fetal isoforms of collagen type 4, ie, COL4A1 and COL4A2, whereas the mature isoforms COL4A3, COL4A4, and COL4A5 were not found to be significantly regulated (Supplemental Table S4, see http:// ajp.amjpathol.org). The expression of these fetal collagen isoforms resembles that seen in Alport syndrome, in which it has been related to a potentially more vulnerable glomerular basement membrane composition ultimately leading to glomerulosclerosis. ${ }^{43,47}$ Such re-expression of fetal collagen genes in glomeruli from adult patients with NSC may be part of an increased cellular plasticity (see below).

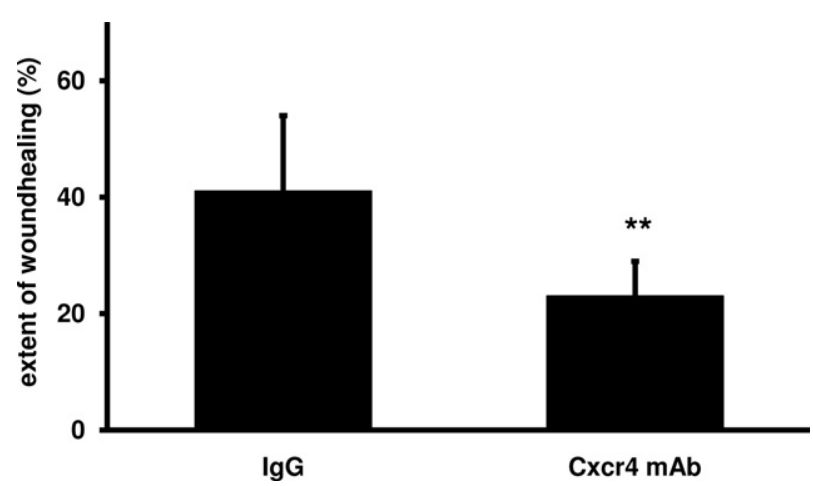

Figure 7. CXCR4 blockade reduces podocyte migration in vitro in a woundhealing assay. To assess potential functions of CXCR4 in podocyte migration, a wound-healing assay was performed. Confluent murine podocytes (K5P5) were treated with either blocking anti-CXCR 4 antibody or immunoglobulin IgG as control. At 0 hours and after 22 hours, the width of each scratch inflicted at 0 hours was measured in a blinded fashion. The CXCR4 antibody significantly impaired the extent of wound closure compared with controls ( $23 \pm 6$ versus $41 \pm 13 \%,{ }^{* *} P<0.01, n=12$ each). mAb, monoclonal antibody.
Inflammation is another biological process closely linked to hypoxia and to progression of renal disease. ${ }^{1,48}$ The complex interplay between hypoxia and the immune system is nicely illustrated by the example of nuclear factor $-\kappa \mathrm{B}$, a master switch in the inflammatory response: $\mathrm{HIF} 1 \alpha$ has been shown to activate nuclear factor- $\kappa \mathrm{B}$ and nuclear factor- $\kappa \mathrm{B}$ itself is a transcriptional activator of HIF1 $\alpha{ }^{48,49}$ Indeed, inflammatory gene signatures were significantly altered in NSC glomeruli (Supplemental Table S3, see http://ajp.amipathol.org) including major histocompatibility class I and II genes, interleukins, and chemokines. Although glomerular inflammatory cell infiltrates have been observed in NSC, ${ }^{50}$ they are not a prominent feature of glomerular NSC. ${ }^{11,12}$ In addition, it should be noted that the expression of "inflammatory" genes cannot be directly equated with inflammatory infiltrates, as some of these genes could be regulated on intrinsic glomerular cells, for which our observations with CXCR4 on podocytes may serve as example.

Among the HIF target genes involved in inflammation, the chemokine receptor CXCR4 was found to be prominently induced in NSC glomeruli. Interestingly, induction of CXCR4 mRNA was not seen by RT-PCR in other glomerulopathies such as FSGS, IgAN, or MCD. For IgAN and membranous nephropathy, the absence of prominent CXCR4 expression in glomeruli had been reported previously. ${ }^{8,51}$ Although FSGS is characterized by glomerular sclerosis similar to NSC, CXCR4 mRNA was not consistently induced in glomeruli from biopsy specimens of patients with primary FSGS. Although immunohistological analysis also revealed CXCR4 positivity of podocytes in FSGS biopsy specimens, the nuclear HIF1 $\alpha$ staining in these biopsy specimens seemed restrained and heterogeneous. In this context, it should be noted that CXCR4 transcriptional regulation also includes HIF- and hypoxiaindependent mechanisms. ${ }^{52-54}$ In FSGS, the primary pathology may be of direct glomerular origin whereas narrowing of the afferent blood vessels with consecutive glomerular hypoxia may be a central mechanism in NSC. Nuclear HIF $1 \alpha$ in podocytes of NSC biopsy specimens can be seen as a biological indicator for hypoxia-associated transcriptional processes. Because nuclear HIF1 $\alpha$ was associated with CXCR4 expression in podocytes of NSC biopsy specimens, we went on to study CXCR4 
expression in podocytes in vitro. In cultured human and murine podocytes, we found a low but constitutive expression of CXCR4/Cxcr4, as was also reported by Huber et al. ${ }^{51}$ Hypoxia in vitro stabilized $\mathrm{HIF} 1 \alpha$ and $\mathrm{HIF} 2 \alpha$ protein and induced CXCR4/Cxcr4 mRNA expression in podocytes. In our experiments we used $\operatorname{HIF} 1 \alpha$ as a global biological marker of hypoxia. However, HIF2 $\alpha$ has been shown to be of specific functional relevance in podocytes. ${ }^{9}$ Although providing clear evidence for an activation of hypoxia-associated transcriptional programs in podocytes, our descriptive data do not elucidate which HIF $\alpha$ subunit or mechanism is mainly regulating CXCR4 in podocytes. However, induction of CXCR4 by hypoxia has been reported for several cell types, such as monocytes, macrophages, endothelial cells, cancer cells, and stem/progenitor cells. ${ }^{52,55-57}$ Von HippelLindau tumor suppressor protein/HIF-dependent regulation of $\mathrm{Cxcr} 4$ on podocytes in vivo was elegantly demonstrated in a study by Ding et $\mathrm{al}^{8}$ in mice with genetically engineered deletion of von Hippel-Lindau tumor suppressor protein in podocytes, leading to glomerular epithelial cell proliferation and extracapillary crescent formation. In this model, interference with CXCR4 signaling prevented the proliferation of the epithelial cells and markedly improved the course of the experimental disease. ${ }^{8}$

Recently, CXCR4 expression on some glomerular parietal epithelial cells of Bowman's capsule has been reported. These parietal cells also express markers for progenitor cells as well as for podocytes. ${ }^{58-60}$ In general, CXCR4 is expressed on stem cells and is involved in their recruitment to sites of tissue regeneration. ${ }^{61-63}$ Potentially, such podocyte precursors of glomerular parietal epithelial cell origin may be involved in the repopulation of the glomerular tuft during podocyte injury. ${ }^{58-60,64}$ CXCR4/CXCL12 guide cell migration in a number of systems (eg, renal morphogenesis (tubulogenesis), neuron/ axon development, and tumor metastasis ${ }^{65-68}$ ). Using an in vitro wound healing assay to evaluate CXCR4-dependent migration, we could demonstrate that treatment of cultured podocytes with a blocking CXCR4 antibody significantly impaired in vitro wound healing and hence CXCR4-dependent cell migration. Potentially, these in vitro data indicate that in vivo CXCR4 is involved in the migration of podocytes during hypoxic injury such as that occurring in NSC. Supporting this observation, we found CXCL12 to be expressed in podocytes in adults, as has been recently reported in the developing murine kidney. ${ }^{8,69}$ CXCL12 was also reported to be expressed by mesangial cells in the developing human ${ }^{70}$ and murine glomerulus. ${ }^{8}$ Future studies on the expression of CXCL12 and CXCR4 during glomerular development and disease should provide further insight into the respective roles and interplay of both molecules in the glomerulus.

Finally, the neo-expression of CXCR4 on podocytes in NSC could reflect a change of differentiation of these epithelial cells re-expressing developmental genes. Although considerable controversy exists in the literature, cellular plasticity has been reported for renal cells. ${ }^{71}$ Tubular cells may change their differentiation during hypoxia, ${ }^{3,72}$ and podocytes have also been reported to be capable of undergoing changes of differentiation in vitro. ${ }^{73,74}$ We found potential markers for a change of differentiation in the microarray gene expression analysis of glomeruli from NSC, eg, down-regulation of the epithelial marker keratin $1(q<0.01)$ and up-regulation of the mesenchymal markers $\mathrm{S} 100$ calcium binding protein A4 $(q<0.01)$ and smooth muscle actin, $\alpha 2(q<0.01)$ (Supplemental Table S1, see http://ajp.amjpathol.org). These observations could point to a role of hypoxia for potential plasticity in podocyte differentiation.

In summary, our data provide evidence for prominent hypoxia-regulated gene expression in glomeruli from human renal biopsy specimens from patients with NSC. This includes biological processes known to be involved in renal damage such as fibrosis and inflammation. Furthermore, our data indicate a reactivation of developmental processes, pointing to considerable plasticity of podocytes during hypoxic glomerular damage. Our observations expand evidence for the contribution of hypoxia from the previously documented role in interstitial fibrosis and tubular damage to that of glomerular sclerosis in NSC.

\section{Acknowledgments}

We thank Claudia Schmidt, Stefanie Gaiser, and Sylke Rohrer for excellent technical assistance. We are indebted to Anissa Boucherot, Almut Nitsche, Bodo Brunner (SanofiAventis Deutschland GmbH, Frankfurt, Germany), and Anna Henger (University of Michigan).

We thank all participating centers of the European Renal cDNA Bank-Kroener-Fresenius biopsy bank and their patients for their cooperation. Active members at the time of the study were Clemens David Cohen, Holger Schmid, Michael Fischereder, Lutz Weber, Matthias Kretzler, and Detlef Schlöndorff, Munich/Zurich/Ann Arbor/New York; Jean Daniel Sraer and Pierre Ronco, Paris; Maria Pia Rastaldi and Giuseppe D'Amico, Milan; Peter Doran and Hugh Brady, Dublin; Detlev Mönks and Christoph Wanner, Würzburg; Andrew Rees, Aberdeen; Frank Strutz and Gerhard Anton Müller, Göttingen; Peter Mertens and Jürgen Floege, Aachen; Norbert Braun and Teut Risler, Tübingen; Loreto Gesualdo and Francesco Paolo Schena, Bari; Jens Gerth and Gunter Wolf, Jena; Rainer Oberbauer and Dontscho Kerjaschki, Vienna; Bernhard Banas and Bernhard Krämer, Regensburg; Moin Saleem, Bristol; Rudolf Wüthrich, Zurich; Walter Samtleben, Munich; Harm Peters and Hans-Hellmut Neumayer, Berlin; Mohamed Daha, Leiden; Katrin Ivens and Bernd Grabensee, Düsseldorf; Francisco Mampaso (deceased), Madrid; Jun Oh, Franz Schaefer, Martin Zeier, and Hermann-Joseph Gröne, Heidelberg; Peter Gross, Dresden; Giancarlo Tonolo, Sassari; Vladimir Tesar, Prague; Harald Rupprecht, Bayreuth; and Hans-Peter Marti, Bern.

\section{References}

1. Fine LG, Norman JT: Chronic hypoxia as a mechanism of progression of chronic kidney diseases: from hypothesis to novel therapeutics. Kidney Int 2008, 74:867-872 
2. Haase VH: The VHL/HIF oxygen-sensing pathway and its relevance to kidney disease. Kidney Int 2006, 69:1302-1307

3. Higgins DF, Kimura K, Bernhardt WM, Shrimanker N, Akai Y, Hohenstein B, Saito Y, Johnson RS, Kretzler M, Cohen CD, Eckardt KU, Iwano M, Haase VH: Hypoxia promotes fibrogenesis in vivo via HIF-1 stimulation of epithelial-to-mesenchymal transition. J Clin Invest 2007, 117:3810-3820

4. Higgins DF, Kimura K, Iwano M, Haase VH: Hypoxia-inducible factor signaling in the development of tissue fibrosis. Cell Cycle 2008, 7:1128-1132

5. Haase VH: Hypoxia-inducible factors in the kidney. Am J Physiol Renal Physiol 2006, 291:F271-F281

6. Brukamp K, Jim B, Moeller MJ, Haase VH: Hypoxia and podocytespecific Vhlh deletion confer risk of glomerular disease. Am J Physiol Renal Physiol 2007, 293:F1397-F1407

7. Freeburg PB, Robert B, St John PL, Abrahamson DR: Podocyte expression of hypoxia-inducible factor (HIF)-1 and HIF-2 during glomerular development. J Am Soc Nephrol 2003, 14:927-938

8. Ding M, Cui S, Li C, Jothy S, Haase V, Steer BM, Marsden PA, Pippin J, Shankland S, Rastaldi MP, Cohen CD, Kretzler M, Quaggin SE: Loss of the tumor suppressor Vhlh leads to upregulation of Cxcr4 and rapidly progressive glomerulonephritis in mice. Nat Med 2006, 12:1081-1087

9. Rosenberger C, Mandriota S, Jurgensen JS, Wiesener MS, Horstrup $\mathrm{JH}$, Frei U, Ratcliffe PJ, Maxwell PH, Bachmann S, Eckardt KU: Expression of hypoxia-inducible factor- $1 \alpha$ and $-2 \alpha$ in hypoxic and ischemic rat kidneys. J Am Soc Nephrol 2002, 13:1721-1732

10. U.S. Renal Data System: USRDS 2008 Annual Data Report: Atlas of Chronic Kidney Disease and End-Stage Renal Disease in the United States. Bethesda, MD, National Institutes of Health, National Institute of Diabetes and Digestive and Kidney Diseases, 2008

11. Tisher CC, Brenner BM: Benign and malignant nephrosclerosis and renovascular disease. Renal Pathology, with Clinical and Functional Correlations, vol 2. Philadelphia, Lippincott, 1994, pp 1202-1203

12. Churg J, Sobin LH: Renal Disease: Benign nephrosclerosis. Classification and Atlas of Glomerular Diseases. Tokyo, Igaku-Shoin, 1982, pp 211-224

13. Marcantoni C, Fogo AB: A perspective on arterionephrosclerosis: from pathology to potential pathogenesis. J Nephrol 2007, 20:518-524

14. Fogo A, Breyer JA, Smith MC, Cleveland WH, Agodoa L, Kirk KA, Glassock R: Accuracy of the diagnosis of hypertensive nephrosclerosis in African Americans: a report from the African American Study of Kidney Disease (AASK) Trial. AASK Pilot Study Investigators. Kidney Int 1997, 51:244-252

15. Schlessinger SD, Tankersley MR, Curtis JJ: Clinical documentation of end-stage renal disease due to hypertension. Am J Kidney Dis 1994, 23:655-660

16. Marcantoni C, Ma LJ, Federspiel C, Fogo AB: Hypertensive nephrosclerosis in African Americans versus Caucasians. Kidney Int 2002, 62:172-180

17. Freedman BI, Sedor JR: Hypertension-associated kidney disease: perhaps no more. J Am Soc Nephrol 2008, 19:2047-2051

18. Kopp JB, Smith MW, Nelson GW, Johnson RC, Freedman BI, Bowden DW, Oleksyk T, McKenzie LM, Kajiyama $H$, Ahuja TS, Berns JS, Briggs W, Cho ME, Dart RA, Kimmel PL, Korbet SM, Michel DM, Mokrzycki MH, Schelling JR, Simon E, Trachtman H, Vlahov D, Winkler CA: MYH9 is a major-effect risk gene for focal segmental glomerulosclerosis. Nat Genet 2008, 40:1175-1184

19. Kao WH, Klag MJ, Meoni LA, Reich D, Berthier-Schaad Y, Li M, Coresh J, Patterson N, Tandon A, Powe NR, Fink NE, Sadler JH, Weir MR, Abboud HE, Adler SG, Divers J, lyengar SK, Freedman Bl, Kimmel PL, Knowler WC, Kohn OF, Kramp K, Leehey DJ, Nicholas SB, Pahl MV Schelling JR, Sedor JR, Thornley-Brown D, Winkler CA, Smith MW, Parekh RS: MYH9 is associated with nondiabetic end-stage renal disease in African Americans. Nat Genet 2008, 40:1185-1192

20. Freedman BI, Iskandar SS, Appel RG: The link between hypertension and nephrosclerosis. Am J Kidney Dis 1995, 25:207-221

21. Wang PX, Sanders PW: Mechanism of hypertensive nephropathy in the Dahl/Rapp rat: a primary disorder of vascular smooth muscle. Am J Physiol Renal Physiol 2005, 288:F236-F242

22. Cohen CD, Frach K, Schlondorff D, Kretzler M: Quantitative gene expression analysis in renal biopsies: a novel protocol for a highthroughput multicenter application. Kidney Int 2002, 61:133-140

23. Cohen CD, Klingenhoff A, Boucherot A, Nitsche A, Henger A, Brunner B, Schmid H, Merkle M, Saleem MA, Koller KP, Werner T, Grone HJ, Nelson PJ, Kretzler M: Comparative promoter analysis allows de novo identification of specialized cell junction-associated proteins. Proc Natl Acad Sci USA 2006, 103:5682-5687

24. Schmid $H$, Boucherot $A$, Yasuda $Y$, Henger $A$, Brunner $B$, Eichinger $F$, Nitsche A, Kiss E, Bleich M, Grone HJ, Nelson PJ, Schlondorff D, Cohen $\mathrm{CD}$, Kretzler M: Modular activation of nuclear factor- $\kappa \mathrm{B}$ transcriptional programs in human diabetic nephropathy. Diabetes 2006, 55:2993-3003

25. Tusher VG, Tibshirani R, Chu G: Significance analysis of microarrays applied to the ionizing radiation response. Proc Natl Acad Sci USA 2001, 98:5116-5121

26. Cohen CD, Lindenmeyer MT, Eichinger F, Hahn A, Seifert M, Moll AG, Schmid H, Kiss E, Grone E, Grone HJ, Kretzler M, Werner T, Nelson PJ: Improved elucidation of biological processes linked to diabetic nephropathy by single probe-based microarray data analysis. PLoS One 2008, 3:e2937

27. Li C, Wong WH: Model-based analysis of oligonucleotide arrays: expression index computation and outlier detection. Proc Natl Acad Sci USA 2001, 98:31-36

28. Hosack DA, Dennis G Jr, Sherman BT, Lane HC, Lempicki RA: Identifying biological themes within lists of genes with EASE. Genome Biol 2003, 4:R70

29. Segerer S, Heller F, Lindenmeyer MT, Schmid H, Cohen CD, Draganovici D, Mandelbaum J, Nelson PJ, Grone HJ, Grone EF, Figel AM, Nossner E, Schlondorff D: Compartment specific expression of dendritic cell markers in human glomerulonephritis. Kidney Int 2008, 74:37-46

30. Mundel P, Reiser J, Zuniga Mejia Borja A, Pavenstadt H, Davidson GR, Kriz W, Zeller R: Rearrangements of the cytoskeleton and cell contacts induce process formation during differentiation of conditionally immortalized mouse podocyte cell lines. Exp Cell Res 1997, 236:248-258

31. Delarue F, Virone A, Hagege J, Lacave R, Peraldi MN, Adida C, Rondeau E, Feunteun J, Sraer JD: Stable cell line of T-SV40 immortalized human glomerular visceral epithelial cells. Kidney Int 1991, 40:906-912

32. Saleem MA, O'Hare MJ, Reiser J, Coward RJ, Inward CD, Farren T, Xing CY, Ni L, Mathieson PW, Mundel P: A conditionally immortalized human podocyte cell line demonstrating nephrin and podocin expression. J Am Soc Nephrol 2002, 13:630-638

33. Lindenmeyer MT, Kretzler M, Boucherot A, Berra S, Yasuda $Y$, Henger A, Eichinger F, Gaiser S, Schmid H, Rastaldi MP, Schrier RW, Schlondorff D, Cohen CD: Interstitial vascular rarefaction and reduced VEGF-A expression in human diabetic nephropathy. J Am Soc Nephrol 2007, 18:1765-1776

34. Moll AG, Lindenmeyer MT, Kretzler M, Nelson PJ, Zimmer R, Cohen $\mathrm{CD}$ : Transcript-specific expression profiles derived from sequencebased analysis of standard microarrays. PLoS One 2009, 4:e4702

35. Catania JM, Chen G, Parrish AR: Role of matrix metalloproteinases in renal pathophysiologies. Am J Physiol Renal Physiol 2007, 292:F905-F911

36. Eddy AA: Molecular basis of renal fibrosis. Pediatr Nephrol 2000, 15:290-301

37. Eikmans M, Baelde JJ, de Heer E, Bruijn JA: ECM homeostasis in renal diseases: a genomic approach. J Pathol 2003, 200:526-536

38. Zeisberg M, Strutz F, Muller GA: Renal fibrosis: an update. Curr Opin Nephrol Hypertens 2001, 10:315-320

39. Manalo DJ, Rowan A, Lavoie T, Natarajan L, Kelly BD, Ye SQ, Garcia JG, Semenza GL: Transcriptional regulation of vascular endothelial cell responses to hypoxia by HIF-1. Blood 2005, 105:659-669

40. Wenger RH, Stiehl DP, Camenisch G: Integration of oxygen signaling at the consensus HRE. Sci STKE 2005, 2005:re12

41. Milner R, Hung S, Erokwu B, Dore-Duffy P, LaManna JC, del Zoppo GJ: Increased expression of fibronectin and the $\alpha 5 \beta 1$ integrin in angiogenic cerebral blood vessels of mice subject to hypobaric hypoxia. Mol Cell Neurosci 2008, 38:43-52

42. Distler JH, Jungel A, Pileckyte M, Zwerina J, Michel BA, Gay RE, KowalBielecka O, Matucci-Cerinic M, Schett G, Marti HH, Gay S, Distler O: Hypoxia-induced increase in the production of extracellular matrix proteins in systemic sclerosis. Arthritis Rheum 2007, 56:4203-4215

43. Hudson BG, Tryggvason K, Sundaramoorthy M, Neilson EG: Alport's syndrome. Goodpasture's syndrome, and type IV collagen, N Engl J Med 2003, 348:2543-2556

44. Gröne HJ, Simon M, Gröne EF: Expression of vascular endothelial 
growth factor in renal vascular disease and renal allografts. J Pathol 1995, 177:259-267

45. Baelde HJ, Eikmans M, Lappin DW, Doran PP, Hohenadel D, Brinkkoetter PT, van der Woude FJ, Waldherr R, Rabelink TJ, de Heer E, Bruijn JA: Reduction of VEGF-A and CTGF expression in diabetic nephropathy is associated with podocyte loss. Kidney Int 2007, 71:637-645

46. Bluyssen HA, Lolkema MP, van Beest M, Boone M, Snijckers CM, Los M, Gebbink MF, Braam B, Holstege FC, Giles RH, Voest EE: Fibronectin is a hypoxia-independent target of the tumor suppressor VHL. FEBS Lett 2004, 556:137-142

47. Gubler MC: Inherited diseases of the glomerular basement membrane. Nat Clin Pract Nephrol 2008, 4:24-37

48. Rius J, Guma M, Schachtrup C, Akassoglou K, Zinkernagel AS, Nizet V, Johnson RS, Haddad GG, Karin M: NF- $\kappa$ B links innate immunity to the hypoxic response through transcriptional regulation of HIF- $1 \alpha$. Nature 2008, 453:807-811

49. Walmsley SR, Print C, Farahi N, Peyssonnaux C, Johnson RS, Cramer T, Sobolewski A, Condliffe AM, Cowburn AS, Johnson N, Chilvers ER: Hypoxia-induced neutrophil survival is mediated by HIF- $1 \alpha$-dependent NF- $\kappa$ B activity. J Exp Med 2005, 201:105-115

50. Imakiire T, Kikuchi Y, Yamada M, Kushiyama T, Higashi K, Hyodo N, Yamamoto K, Oda T, Suzuki S, Miura S: Effects of renin-angiotensin system blockade on macrophage infiltration in patients with hypertensive nephrosclerosis. Hypertens Res 2007, 30:635-642

51. Huber TB, Reinhardt HC, Exner M, Burger JA, Kerjaschki D, Saleem MA, Pavenstadt H: Expression of functional CCR and CXCR chemokine receptors in podocytes. J Immunol 2002, 168:6244-6252

52. Staller P, Sulitkova J, Lisztwan J, Moch H, Oakeley EJ, Krek W: Chemokine receptor CXCR4 downregulated by von Hippel-Lindau tumour suppressor pVHL. Nature 2003, 425:307-311

53. Mori T, Kim J, Yamano T, Takeuchi H, Huang S, Umetani N, Koyanagi $\mathrm{K}$, Hoon DS: Epigenetic up-regulation of $\mathrm{C}-\mathrm{C}$ chemokine receptor 7 and $\mathrm{C}-\mathrm{X}-\mathrm{C}$ chemokine receptor 4 expression in melanoma cells. Cancer Res 2005, 65:1800-1807

54. Mehta SA, Christopherson KW, Bhat-Nakshatri P, Goulet RJ Jr, Broxmeyer HE, Kopelovich L, Nakshatri $\mathrm{H}$ : Negative regulation of chemokine receptor CXCR4 by tumor suppressor p53 in breast cancer cells: implications of p53 mutation or isoform expression on breast cancer cell invasion. Oncogene 2007, 26:3329-3337

55. Schioppa T, Uranchimeg B, Saccani A, Biswas SK, Doni A, Rapisarda A, Bernasconi S, Saccani S, Nebuloni M, Vago L, Mantovani A, Melillo G, Sica A: Regulation of the chemokine receptor CXCR4 by hypoxia. J Exp Med 2003, 198:1391-1402

56. Zagzag D, Krishnamachary B, Yee H, Okuyama H, Chiriboga L, Ali MA, Melamed J, Semenza GL: Stromal cell-derived factor- $1 \alpha$ and CXCR4 expression in hemangioblastoma and clear cell-renal cell carcinoma: von Hippel-Lindau loss-of-function induces expression of a ligand and its receptor. Cancer Res 2005, 65:6178-6188

57. Hung SC, Pochampally RR, Hsu SC, Sanchez C, Chen SC, Spees J, Prockop DJ: Short-term exposure of multipotent stromal cells to low oxygen increases their expression of CX3CR1 and CXCR4 and their engraftment in vivo. PLoS ONE 2007, 2:e416

58. Sagrinati C, Netti GS, Mazzinghi B, Lazzeri E, Liotta F, Frosali F, Ronconi E, Meini C, Gacci M, Squecco R, Carini M, Gesualdo L, Francini F, Maggi E, Annunziato F, Lasagni L, Serio M, Romagnani S, Romagnani P: Isolation and characterization of multipotent progenitor cells from the Bowman's capsule of adult human kidneys. J Am Soc Nephrol 2006, 17:2443-2456
59. Ronconi E, Sagrinati C, Angelotti ML, Lazzeri E, Mazzinghi B, Ballerini L, Parente E, Becherucci F, Gacci M, Carini M, Maggi E, Serio M, Vannelli GB, Lasagni L, Romagnani S, Romagnani P: Regeneration of glomerular podocytes by human renal progenitors. J Am Soc Nephrol 2009, 20:322-332

60. Mazzinghi B, Ronconi E, Lazzeri E, Sagrinati C, Ballerini L, Angelotti ML, Parente E, Mancina R, Netti GS, Becherucci F, Gacci M, Carini M, Gesualdo L, Rotondi M, Maggi E, Lasagni L, Serio M, Romagnani S, Romagnani P: Essential but differential role for CXCR4 and CXCR7 in the therapeutic homing of human renal progenitor cells. J Exp Med 2008, 205:479-490

61. Ceradini DJ, Kulkarni AR, Callaghan MJ, Tepper OM, Bastidas N, Kleinman ME, Capla JM, Galiano RD, Levine JP, Gurtner GC: Progenitor cell trafficking is regulated by hypoxic gradients through HIF-1 induction of SDF-1. Nat Med 2004, 10:858-864

62. Lapidot T, Kollet O: The essential roles of the chemokine SDF-1 and its receptor CXCR4 in human stem cell homing and repopulation of transplanted immune-deficient NOD/SCID and NOD/SCID/B2m null mice. Leukemia 2002, 16:1992-2003

63. Ceradini DJ, Gurtner GC: Homing to hypoxia: hIF-1 as a mediator of progenitor cell recruitment to injured tissue. Trends Cardiovasc Med 2005, 15:57-63

64. Appel D, Kershaw DB, Smeets B, Yuan G, Fuss A, Frye B, Elger M, Kriz W, Floege J, Moeller MJ: Recruitment of podocytes from glomerular parietal epithelial cells. J Am Soc Nephrol 2009, 20:333-343

65. Ueland J, Yuan A, Marlier A, Gallagher AR, Karihaloo A: A novel role for the chemokine receptor $\mathrm{Cxcr} 4$ in kidney morphogenesis: an in vitro study. Dev Dyn 2009, 238:1083-1091

66. Baudouin SJ, Pujol F, Nicot A, Kitabgi P, Boudin H: Dendrite-selective redistribution of the chemokine receptor CXCR4 following agonist stimulation. Mol Cell Neurosci 2006, 33:160-169

67. Onoue $T$, Uchida D, Begum NM, Tomizuka $Y$, Yoshida H, Sato M: Epithelial-mesenchymal transition induced by the stromal cell-derived factor-1/CXCR4 system in oral squamous cell carcinoma cells. Int J Oncol 2006, 29:1133-1138

68. Pujol F, Kitabgi P, Boudin H: The chemokine SDF-1 differentially regulates axonal elongation and branching in hippocampal neurons. J Cell Sci 2005, 118:1071-1080

69. Takabatake $\mathrm{Y}$, Sugiyama T, Kohara H, Matsusaka T, Kurihara H, Koni PA, Nagasawa Y, Hamano T, Matsui I, Kawada N, Imai E, Nagasawa T, Rakugi H, Isaka Y: The CXCL12 (SDF-1)/CXCR4 axis is essential for the development of renal vasculature. J Am Soc Nephrol 2009, 20:1714-1723

70. Gröne HJ, Cohen CD, Gröne E, Schmidt C, Kretzler M, Schlondorff D, Nelson PJ: Spatial and temporally restricted expression of chemokines and chemokine receptors in the developing human kidney. J Am Soc Nephrol 2002, 13:957-967

71. Kaissling B, Le Hir M: The renal cortical interstitium: morphological and functional aspects. Histochem Cell Biol 2008, 130:247-262

72. Neilson EG: Mechanisms of disease: fibroblasts-a new look at an old problem. Nat Clin Pract Nephrol 2006, 2:101-108

73. Li Y, Kang YS, Dai C, Kiss LP, Wen X, Liu Y: Epithelial-to-mesenchymal transition is a potential pathway leading to podocyte dysfunction and proteinuria. Am J Pathol 2008, 172:299-308

74. Sam R, Wanna L, Gudehithlu KP, Garber SL, Dunea G, Arruda JA, Singh AK: Glomerular epithelial cells transform to myofibroblasts: early but not late removal of TGF- $\beta 1$ reverses transformation. Transl Res 2006, 148:142-148 